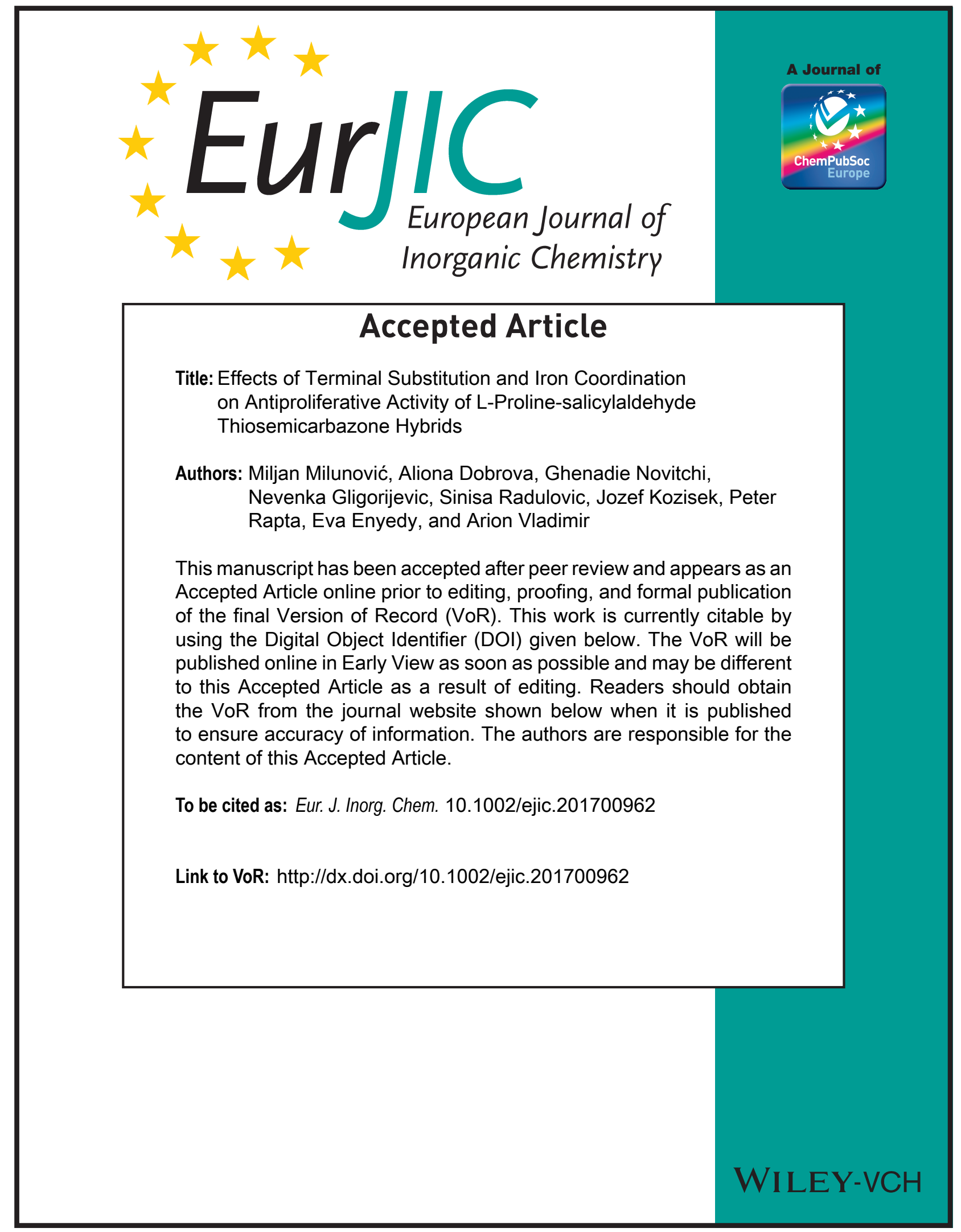




\section{Effects of Terminal Substitution and Iron Coordination on Antiproliferative Activity of L-Proline-salicylaldehyde Thiosemicarbazone Hybrids}

Miljan N. M. Milunović, ${ }^{*[a, d]}$ Aliona Dobrova, ${ }^{[a]}$ Ghenadie Novitchi, ${ }^{[b]}$ Nevenka Gligorijević, ${ }^{[c]}$ Siniša Radulović, ${ }^{[c]}$ Jozef Kožišek, ${ }^{[d]}$ Peter Rapta, ${ }^{[d]}$ Eva A. Enyedy, ${ }^{[e]}$ Vladimir B. Arion ${ }^{*[a]}$

[a] Institute of Inorganic Chemistry,

University of Vienna, Faculty of Chemistry,

Währinger Strasse 42, A-1090, Austria

http://anorg-chemie.univie.ac.at/magnoliaPublic/Research/Bioinorganic-

chemistry/Group-V-Arion.html

E-mail: miljan.milunovic@univie.ac.at; vladimir.arion@univie.ac.at

[b] Laboratoire National des Champs Magnetiques Intenses-CNRS,

25 Avenue des Martyrs 38042 Grenoble Cedex 9, France

[c] Institute for Oncology and Radiology of Serbia,

University of Belgrade,

Pasterova 14, 11000 Belgrade, Serbia

[d] Institute of Physical Chemistry and Chemical Physics,

Slovak University of Technology, Faculty of Chemical and Food Technology,

Radlinského 9, SK-81237 Bratislava, Slovakia

[e] Department of Inorganic and Analytical Chemistry,

University of Szeged,

Dom ter 7, H-6720 Szeged, Hungary

This article is protected by copyright. All rights reserved. 


\section{Abstract}

A series of five iron(III) complexes, namely $\left[\mathrm{Fe}\left(\mathrm{HL}^{1}\right) \mathrm{Cl}_{2}\right]$ (1), $\left[\mathrm{Fe}\left(\mathrm{HL}^{2}\right) \mathrm{Cl}_{2}\right] \cdot 1.6 \mathrm{H}_{2} \mathrm{O}$ (2.1.6 $\left.\mathrm{H}_{2} \mathrm{O}\right), \quad\left[\mathrm{Fe}\left(\mathrm{HL}^{3}\right)(\mathrm{MeOH}) \mathrm{Cl}_{2}\right] \cdot 0.5 \mathrm{H}_{2} \mathrm{O} \quad\left(3 \cdot 0.5 \mathrm{H}_{2} \mathrm{O}\right), \quad\left[\mathrm{Fe}\left(\mathrm{HL}^{4}\right)(\mathrm{MeOH}) \mathrm{Cl}_{2}\right] \cdot 0.5 \mathrm{H}_{2} \mathrm{O}$ $\left(4 \cdot 0.5 \mathrm{H}_{2} \mathrm{O}\right)$ and $\left[\mathrm{Fe}\left(\mathrm{HL}^{4}\right)(\mathrm{dmf}) \mathrm{Cl}_{2}\right] \cdot 0.5 \mathrm{Et}_{2} \mathrm{O} \cdot \mathrm{H}_{2} \mathrm{O}\left(4^{\prime} \cdot 0.5 \mathrm{Et}_{2} \mathrm{O} \cdot \mathrm{H}_{2} \mathrm{O}\right.$, where $\mathrm{H}_{2} \mathrm{~L}^{1}=\mathrm{L}$-proline salicylaldehyde thiosemicarbazone (L-Pro-STSC), $\mathrm{H}_{2} \mathrm{~L}^{2}=$ pyrrolidine substituted L-ProSTSC, $\mathrm{H}_{2} \mathrm{~L}^{3}$ = phenyl substituted L-Pro-STSC and $\mathrm{H}_{2} \mathrm{~L}^{4}=$ naphthyl substituted L-ProSTSC, has been synthesised. The two ligand precursors $\left(\mathrm{H}_{2} \mathrm{~L}^{3}\right.$ and $\left.\mathrm{H}_{2} \mathrm{~L}^{4}\right)$ and iron complexes were characterised by elemental analysis, spectroscopic methods (UV-vis, IR and NMR), ESI mass spectrometry and single crystal X-ray crystallography (1-3 and $\left.4^{\prime}\right)$. Magnetic properties of the five-coordinate complex 2 and six-coordinate complex 4 have been also investigated. The antiproliferative activity of the organic hybrids and their iron(III) complexes have been studied in vitro in five human and one murine cancer cell lines, namely HeLa (cervical cancer), FemX (melanoma), A549 (alveolar basal adenocarcinoma), LS-174 (colon cancer), MDA-MB-453 (breast cancer) and MS1 (transformed murine endothelial), as well as in human noncancerous fetal lung fibroblast cell line (MRC-5). According to structure-activity relationship, introduction of aromatic groups such as phenyl or naphthyl enhances the cytotoxic potency of the hybrids in the following order $\mathrm{H}_{2} \mathrm{~L}^{1}<\mathrm{H}_{2} \mathrm{~L}^{2}<\mathrm{H}_{2} \mathrm{~L}^{3}<\mathrm{H}_{2} \mathrm{~L}^{4}$. Coordination of the hybrids to iron(III) improves their antiproliferative activity in the majority of investigated cell lines with exception of $\mathrm{H}_{2} \mathrm{~L}^{3}$ in LS-174, $\mathrm{H}_{2} \mathrm{~L}^{4}$ in $M S 1$ and both $\mathrm{H}_{2} \mathrm{~L}^{3}$ and $\mathrm{H}_{2} \mathrm{~L}^{4}$ in FemX cell lines, where an opposite effect was observed.

Keywords: iron(III) thiosemicarbazone complexes, antiproliferative activity 


\section{Introduction}

Thiosemicarbazones (TSCs) as excellent metal chelators are a class of organic compounds with structural diversity ${ }^{1,2}$ and broad spectrum of pharmacological activities, such as antiproliferative, antiviral, antibacterial, antimalarial and antifungal. ${ }^{3}$ The research interest in TSCs as antiproliferative agents was aroused in 1950's, when $p$ aminobenzaldehyde thiosemicarbazone was found to inhibit virus multiplication, where the synthesis of nucleoproteins was required. ${ }^{4}$ Later on, by replacement of the benzaldehyde moiety with pyridine-2-carboxaldehyde one, two new compounds, namely, 5-hydroxy-2-formylpyridine thiosemicarbazone (5-HP) ${ }^{5,6}$ and 3-aminopyridine-2carboxaldehyde thiosemicarbazone (Triapine), ${ }^{7}$ were discovered to possess much higher anticancer activity in vitro and in vivo compared to 2-hydroxy-benzaldehyde thiosemicarbazones and promoted to clinical studies. The reason for this cytotoxicity enhancement is still unknown. Triapine was investigated in more than 20 clinical phase I and II trials as anticancer drug candidate, showing mixed results and considerable side effects. ${ }^{8}$ However, it still remains a prominent investigational TSC in fight against cancer.

Two enzymes, namely ribonucleotide reductase (RNR) ${ }^{9}$ and topoisomerase II (topo II), which are responsible for DNA synthesis and (de)catenation of DNA-chain during transcription, as well as replication and repair are predominantly studied as targets in the underlying mechanisms of their antiproliferative activity. It is well known, that disturbance of the enzyme activity (RNR and/or topoll) indirectly leads to cell apoptosis. ${ }^{10}$ Other events such as mitochondrial disruption, ${ }^{11}$ inhibition of multidrug resistance protein, ${ }^{12}$ inhibition of epithelial-to-mesenchymal transition ${ }^{13}$ and inhibition of oncogenic signaling pathways ${ }^{14}$ are also attributed to anticancer activity of TSCs.

Drug design strategies for the enhancement of TSCs cytotoxicity rely on the introduction of either bulky aliphatic and aromatic groups or a heteroatom in the TSC backbone, as well as on metal coordination. $2,8,15,16,17,18$ 
Quite recently, two other members of the TSC family, namely, di-2-pyriylketone 4cyclohexyl-4-methyl-3-thiosemicarbazone (DpC) and (E)- $N^{\prime}$-(6,7-dihydroquinolin)-8(5H)ylidene)-4-(pyridine-2-yl)piperazine-1-carbothiohydrazide (COTI-2) have entered clinical studies, showing multi-target features, ${ }^{19,20}$ and rekindling the research interest in TSCs.

Besides the good cytotoxicity and the selectivity for cancer cells, very often further anticancer investigations are prohibited because of low water solubility and high lipophilicity of TSCs. Finding an appropriate hydrophilicity/lipophilicity balance of a potent anticancer drug candidate is still a challenge. ${ }^{21}$

Rapid tumour growth requires increasing amounts of essential metal ions (iron, copper, zinc). Their deficiency makes cancer cells more sensitive to chemotherapeutics compared to normal cells. ${ }^{11,14,22}$ Complexes of TSCs with essential transition metal ions do not always exhibit better in vitro cytotoxicity than metal-free TSCs alone. 2,8,10,15,16,17,18 According to the previous studies, only few iron TSC complexes showed an improved cytotoxic effect upon coordination to iron. ${ }^{23,24}$ Although they can activate various pathways leading ultimately to cell apoptosis, their mechanism of inhibition of cell proliferation is still unknown. The formation of reactive oxygen species (ROS) which damage cellular processes and leads to cell apoptosis is a feature often attributed to anticancer activity of iron(III) complexes of TSCs. ${ }^{2,25}$ In addition, L-proline is distinct from other amino acids since it is only secondary amino acid. The metabolism of proline is different and takes place in the presence of special enzymes. It is accompanied by formation of signaling ROS for epigenetic reprogramming by oncogenes, and regulates redox homeostasis. These regulatory functions play an important role in apoptosis, autophagy and hypoxia in the presence of low oxygen levels typical for cancer. ${ }^{26}$

Several years ago, we reported on the synthesis of 3-formyl-2-hydroxy-5-methylbenzyl)L-proline and 3-formyl-2-hydroxy-5-methylbenzyl)-D-proline (L-Pro-MSA and D-ProMSA, respectively), which are closely related to monophyllidin (Figure 1), a naturally occurring alkaloid with antibacterial effect towards Enterococcus faecalis. ${ }^{27}$ By condensation reactions with thiosemicarbazides new thiosemicarbazone-proline hybrids 
were synthesized, namely, L-Pro-STSC and D-Pro-STSC with improved water solubility and enhanced anticancer activity, particularly, upon the coordination to the metal. ${ }^{18}$

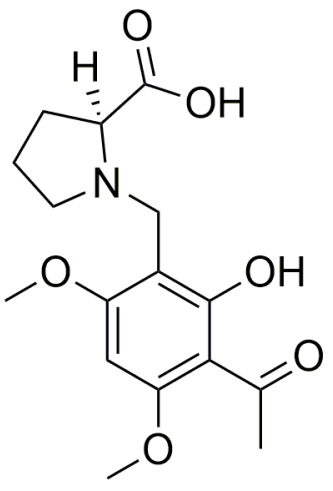

Monophyllidin<smiles>Cc1cc(C=O)c(O)c(CN2CCC[C@H]2C(=O)O)c1</smiles>

L-Pro-MSA<smiles>Cc1cc(/C=N/NC(N)=S)c(O)c(CN2CCC[C@H]2C(=O)O)c1</smiles>

L-Pro-STSC

Figure 1. Line drawings of monophyllidin, L-Pro-MSA and L-Pro-STSC.

These hybrid molecules (L-Pro-STSC and D-Pro-STSC) form mono-ligand complexes with iron(III/II), copper(II) and zinc(II) and, in addition, bis-ligand complexes with iron(III/II). ${ }^{18}$ The metal-free hybrids showed only moderate cytotoxic potency towards colon cancer (SW480) and ovarian cancer $(\mathrm{CH} 1)$ cell lines, while coordination to copper(II) markedly increased their cytotoxicity. The replacement of the phenolic moiety (in L-Pro-STSC) by pyridine (in 3-methyl-(S)-pyrrolidine-2-carboxylate-2-formylpyridine thiosemicarbazone, L-Pro-FTSC) does not significantly improve cytotoxic properties of the hybrids, most probably due to a further enhancement of the hydrophilic character. ${ }^{21}$ The structural modifications at the terminal $\mathrm{N}$ atom of the TSC moiety in L-Pro-STSC and coordination to essential metals had a beneficial impact on the cytotoxicity, while the changes on the proline moiety of the hybrids reduced antiproliferative activity. ${ }^{28}$ The results prompted us to extend the series of L-Pro-STSC conjugates by attachment of aromatic groups at terminal $\mathrm{N}$ atom of TSCs to increase their lipophilic character, and hopefully their cytotoxic potency. We anticipated that L-Pro-STSC $\left(\mathbf{H}_{2} \mathbf{L}^{1}\right)$, Pyrr-L-ProSTSC $\left(\mathbf{H}_{2} \mathrm{~L}^{2}\right)$ and two conjugates namely, phenyl-L-Pro-STSC $\left(\mathbf{H}_{2} \mathrm{~L}^{3}\right)$ and 2-naphthyl-LPro-STSC $\left(\mathrm{H}_{2} \mathrm{~L}^{4}\right)$ will form mono-ligand complexes with iron(III) providing better insight into (i) the role of iron coordination and its effect on antiproliferative activity, (ii) the effect of aromatic groups at terminal $\mathrm{N}$ atom on antiproliferative activity of the conjugates as well as of their iron(III) complexes. 
Herein we report on the synthesis and characterisation of two $\mathrm{N}$-monosubstituted L-ProSTSC conjugates $\left(\mathrm{H}_{2} \mathrm{~L}^{3}\right.$ and $\left.\mathbf{H}_{2} \mathrm{~L}^{4}\right)$ and five iron(III) complexes (1-4 and $\mathbf{4}^{\prime}$ ) which have been prepared and isolated in the solid state (Figure 2) and characterised by elemental analysis, spectroscopic methods, magnetic susceptibility measurements, electrochemistry and X-ray diffraction.

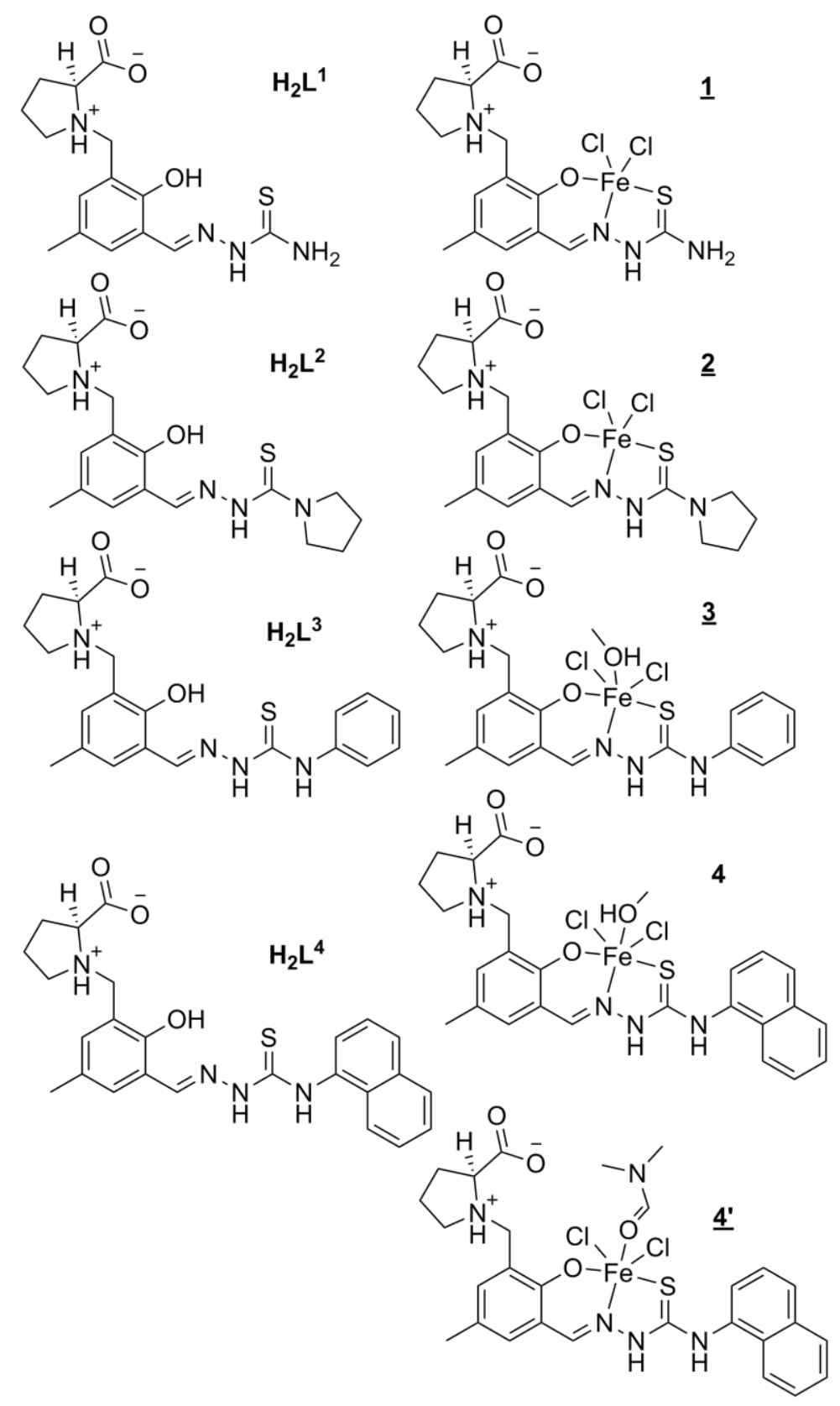

Figure 2. Line drawings of the L-Pro-STSC hybrids and their iron(III) complexes studied in this work. Underlined numbers indicate complexes studied by X-ray diffraction. Cocrystallised solvent molecules were omitted. 
In particular, coordination chemistry of the hybrids (namely, L-Pro-STSC $\left(\mathbf{H}_{2} \mathbf{L}^{\mathbf{1}}\right)$, pyrrolidyl-L-Pro-STSC $\left(\mathrm{H}_{2} \mathrm{~L}^{2}\right)$, phenyl-L-Pro-STSC $\left(\mathrm{H}_{2} \mathrm{~L}^{3}\right)$ and 2-naphthyl-L-Pro-STSC $\left(\mathrm{H}_{2} \mathrm{~L}^{4}\right)$ ), the effects of iron(III) coordination and $\mathrm{N}$-terminal substitution of TSC moiety on cytotoxicity in six human cancer cell lines, namely, cervical cancer cells (HeLa), melanoma cells (FemX), adenocarcinoma alveolar basal cells (A549), colon cancer cells (LS-174), breast cancer cells (MDA-MB-453), murine transformed endothelial cell line (MS1) and noncancerous fetal lung fibroblast (MRC-5) have been investigated and discussed.

\section{Results and discussion}

Synthesis and characterisation of the ligand precursors. The chiral proligands LPro-STSC $\left(\mathbf{H}_{2} \mathbf{L}^{\mathbf{1}}\right)$ and Pyrr-L-Pro-STSC $\left(\mathbf{H}_{2} \mathbf{L}^{2}\right)$ have been synthesised as described previously. ${ }^{18,28}$ The reaction of L-Pro-MSA with 4-phenyl-3-thiosemicarbazide in ethanolwater mixture and 4-(1-naphthyl)-3-thiosemicarbazide in ethanol afforded $\mathrm{H}_{2} \mathrm{~L}^{3}$ and $\mathrm{H}_{2} \mathrm{~L}^{4}$ in 64 and $65 \%$ yield, respectively. ESI mass spectra of $\mathrm{H}_{2} \mathrm{~L}^{3}$ and $\mathrm{H}_{2} \mathrm{~L}^{4}$ measured in negative ion mode showed characteristic peaks with $\mathrm{m} / \mathrm{z} 411$ and 461 attributed to $[\mathrm{M}-\mathrm{H}]^{-}$, while those measured in positive ion mode revealed peaks with $\mathrm{m} / \mathrm{z} 413$ and 485 , respectively, assigned to $[\mathrm{M}+\mathrm{H}]^{+}$and $[\mathrm{M}+\mathrm{Na}]^{+}$. The formation of prolinethiosemicarbazone hybrids $\mathrm{H}_{2} \mathrm{~L}^{3}$ and $\mathrm{H}_{2} \mathrm{~L}^{4}$ was also confirmed by one-dimensional $\left({ }^{1} \mathrm{H}\right.$ and ${ }^{13} \mathrm{C}$ ) and two-dimensional $\left({ }^{1} \mathrm{H}-{ }^{1} \mathrm{H}\right.$ COSY, ${ }^{1} \mathrm{H}-{ }^{13} \mathrm{C}$ HMBC and $\left.\mathrm{HSQC}\right)$ NMR measurements (see experimental part and Figures S1-S14).

Synthesis and characterisation of iron(III) complexes. Iron(III) complexes 1-3 have been prepared by reaction of $\mathrm{FeCl}_{3} \cdot 6 \mathrm{H}_{2} \mathrm{O}$ with the corresponding proligand $\left(\mathbf{H}_{2} \mathbf{L}^{1}, \mathbf{H}_{2} \mathbf{L}^{2}\right.$ or $\mathrm{H}_{2} \mathrm{~L}^{3}$ ) in methanol. A small excess of iron(III) salt (ca. 0.3 equiv) assured the formation of the mono-ligand complexes $\left[\mathrm{Fe}\left(\mathrm{HL}^{1-3}\right) \mathrm{Cl}_{2}\right]$. Vapour diffusion of $\mathrm{Et}_{2} \mathrm{O}$ in methanolic solution of the complexes afforded $X$-ray diffraction quality crystals of 1-3 in 25, 33 and $61 \%$ yield, respectively. Complex 4 resulted from reaction of $\mathrm{FeCl}_{3} \cdot 6 \mathrm{H}_{2} \mathrm{O}$ with $\mathrm{H}_{2} \mathrm{~L}^{4}$ in ethanol/water mixture (1:1). Evapouration of the solvent under reduced pressure followed by dissolution of the residue in methanol and precipitation with $\mathrm{Et}_{2} \mathrm{O}$ 
gave rise to pure solid 4. By vapour diffusion of $\mathrm{Et}_{2} \mathrm{O}$ into the solution of 4, in dimethylformamide (dmf), single crystals of 4' were obtained.

All iron(III) complexes were characterised by elemental analysis, IR (Figures S15-S19), UV-vis, CD spectroscopy and ESI mass spectrometry. ESI mass spectra of iron(III) complexes in negative ion mode exhibited strong peaks with $m / z 459,514,537$ and 586, respectively, attributed to $\left[\mathrm{Fe}\left(\mathrm{L}^{1}\right) \mathrm{Cl}_{2}\right]^{-},\left[\mathrm{Fe}\left(\mathrm{L}^{2}\right) \mathrm{Cl}_{2}\right]^{-},\left[\mathrm{Fe}\left(\mathrm{L}^{3}\right) \mathrm{Cl}_{2}\right]^{-}$and $\left[\mathrm{Fe}\left(\mathrm{L}^{4}\right) \mathrm{Cl}_{2}\right]^{-}$, respectively, while in positive ion mode peaks assigned to $\left[\mathrm{Fe}\left(\mathrm{H}_{2} \mathrm{~L}^{1-4}\right)\right]^{+}$were observed (see Experimental part). UV-vis spectra of 1-4 in methanol and 4' in dmf showed intraligand transitions and metal-to-ligand charge transfer bands between 250 and 600 $\mathrm{nm}$ (Figure S20-S24). In CD spectra of 1-4 (Figure S25) the presence of enantiomeric excess was observed due to the chiral L-proline moiety in the complexes. The structures of the iron complexes in the solid state were established by single crystal X-ray diffraction.

X-ray crystallography. The results of X-ray diffraction studies of $\mathbf{1}$, $2 \cdot 0.2 \mathrm{CH}_{3} \mathrm{OH} \cdot 0.125 \mathrm{Et}_{2} \mathrm{O} \cdot 0.063 \mathrm{H}_{2} \mathrm{O}, 3 \cdot 0.5 \mathrm{CH}_{3} \mathrm{OH}$ and $4^{\prime} \cdot \mathrm{Et}_{2} \mathrm{O}$ are shown in Figure 3 and 4, respectively, with selected geometric parameters quoted in the legends. The compounds 1-3 and 4' crystallised in the noncentrosymmetric space groups $P 1, P 3_{22} 1$, $P 2_{1}$ and $P 22_{2} 2_{1}$, respectively, as pure enantiomers, as confirmed by the Flack parameters in Table 1. The asymmetric unit of 1 consists of four independent molecules of the iron(III) complex [Fe( $\left.\mathrm{HL}^{1}\right)^{\mathrm{Cl}} \mathrm{Cl}_{2}$, while that of $2 \cdot 0.2 \mathrm{CH}_{3} \mathrm{OH} \cdot 0.125 \mathrm{Et} 2 \mathrm{O} \cdot 0.063 \mathrm{H}_{2} \mathrm{O}$ of two crystallographically independent molecules of $\left[\mathrm{Fe}\left(\mathbf{H L}^{2}\right) \mathrm{Cl}_{2}\right]$ and co-crystallised solvent.

The ligands in complexes 1 and 2 act as tridentate monoprotonated species $\left(\mathrm{HL}^{1}\right)^{-}$and $\left(\mathrm{HL}^{2}\right)^{-}$coordinating to iron(III) via the phenolato oxygen atom $\mathrm{O} 1 \mathrm{a}$, the nitrogen atom $\mathrm{N} 1 \mathrm{a}$ and the thione sulfur S1a as shown for one crystallographically independent complex in Figure 3. The coordination polyhedron of iron(III) is close to squarepyramidal ( $\tau$ is 0.12 and 0.15 in 1 and 2 , respectively) ${ }^{29}$ and is completed by two chlorido ligands, one in the basal plane, while another in the apical position. The proline moiety adopts the zwitterionic form and is not involved in coordination to iron(III). 
Table 1. Crystal data and details of data collection for iron(III) complexes.

\begin{tabular}{|c|c|c|c|c|}
\hline Compound & 1 & $2 \cdot 0.2 \mathrm{CH}_{3} \mathrm{OH} \cdot 0.125 \mathrm{Et}_{2} \mathrm{O} \cdot 0.063 \mathrm{H}_{2} \mathrm{O}$ & $3 \cdot 0.5 \mathrm{CH}_{3} \mathrm{OH}$ & $4^{\prime} \cdot \mathrm{Et}_{2} \mathrm{O}$ \\
\hline empirical formula & $\mathrm{C}_{15} \mathrm{H}_{19} \mathrm{Cl}_{2} \mathrm{FeN}_{4} \mathrm{O}_{3}$ & $\mathrm{C}_{19.7} \mathrm{H}_{27.18} \mathrm{Cl}_{2} \mathrm{FeN}_{4} \mathrm{O}_{3.39} \mathrm{~S}$ & $\mathrm{C}_{22.5} \mathrm{H}_{29} \mathrm{Cl}_{2} \mathrm{FeN}_{4} \mathrm{O}_{4.5}$ & $\mathrm{C}_{32} \mathrm{H}_{42} \mathrm{Cl}_{2} \mathrm{FeN}_{5} \mathrm{O}_{5} \mathrm{~S}$ \\
\hline $\mathrm{Fw}$ & 462.15 & 533.04 & 586.30 & 735.51 \\
\hline space group & $P 1$ & $P 3_{2} 2_{1}$ & $P 2_{1}$ & $P 2_{1} 2_{1} 2_{1}$ \\
\hline$a[\AA]$ & $11.7228(4)$ & $15.2992(7)$ & $10.0939(3)$ & $15.2295(3)$ \\
\hline$b[\AA]$ & $13.1340(5)$ & $15.2992(7)$ & 19.8953(6) & $13 . \varepsilon^{\prime a n}$ \\
\hline$c[\AA]$ & $14.2125(8)$ & $39.998(2)$ & $12.8165(4)$ & 17.1 \\
\hline$\alpha\left[^{\circ}\right]$ & $106.120(2)$ & & & \\
\hline$\beta\left[^{\circ}\right]$ & $97.415(2)$ & & $101.140(2)$ & \\
\hline$\gamma\left[^{\circ}\right]$ & $113.163(2)$ & & & \\
\hline$V\left[\AA^{3}\right]$ & $1861.10(14)$ & $8107.9(7)$ & 2525.33(13) & 346 \\
\hline$Z$ & 4 & 12 & 4 & 4 \\
\hline$\lambda[\AA]$ & 0.71073 & 0.71073 & 0.71073 & $1.5<$ \\
\hline$\rho_{\text {calcd }}\left[\mathrm{g} \mathrm{cm}^{-3}\right]$ & 1.649 & 1.310 & 1.704 & 1.41 \\
\hline crystal size [mm] & $0.20 \times 0.16 \times 0.16$ & $0.40 \times 0.23 \times 0.15$ & $0.08 \times 0.01 \times 0.01$ & $\times 0.04$ \\
\hline$T[\mathrm{~K}]$ & $120(2)$ & $100(2)$ & $100(2)$ & 100 \\
\hline$\mu\left[\mathrm{mm}^{-1}\right]$ & 1.233 & 0.860 & 7.849 & $5.8 \epsilon$ \\
\hline$R_{1}[\mathrm{a}]$ & 0.0235 & 0.0609 & 0.0614 & $0.0<$ \\
\hline$w R_{2}^{[\mathrm{b}]}$ & 0.0629 & 0.1731 & 0.1549 & $0.1:$ \\
\hline Flack parameter & $-0.002(8)$ & $0.04(3)$ & $-0.001(7)$ & $-0 . c$ \\
\hline $\mathrm{GOF}^{[\mathrm{c}]}$ & 1.020 & 1.177 & 1.003 & $1.0 C$ \\
\hline
\end{tabular}
number of reflections and $p$ is the total number of parameters refined. 
Protonation of $\mathrm{N} 4 \mathrm{a}$ makes this atom in addition to $\mathrm{C} 14 \mathrm{a}$ chiral. Both atoms adopt the same $S$ configuration as observed recently in complexes of nickel(II), palladium(II) and copper(II) with the same type of proline-thiosemicarbazone hybrids. ${ }^{18,28}$ Opposite configurations of these two atoms are also well-documented in the literature. ${ }^{21,30}$
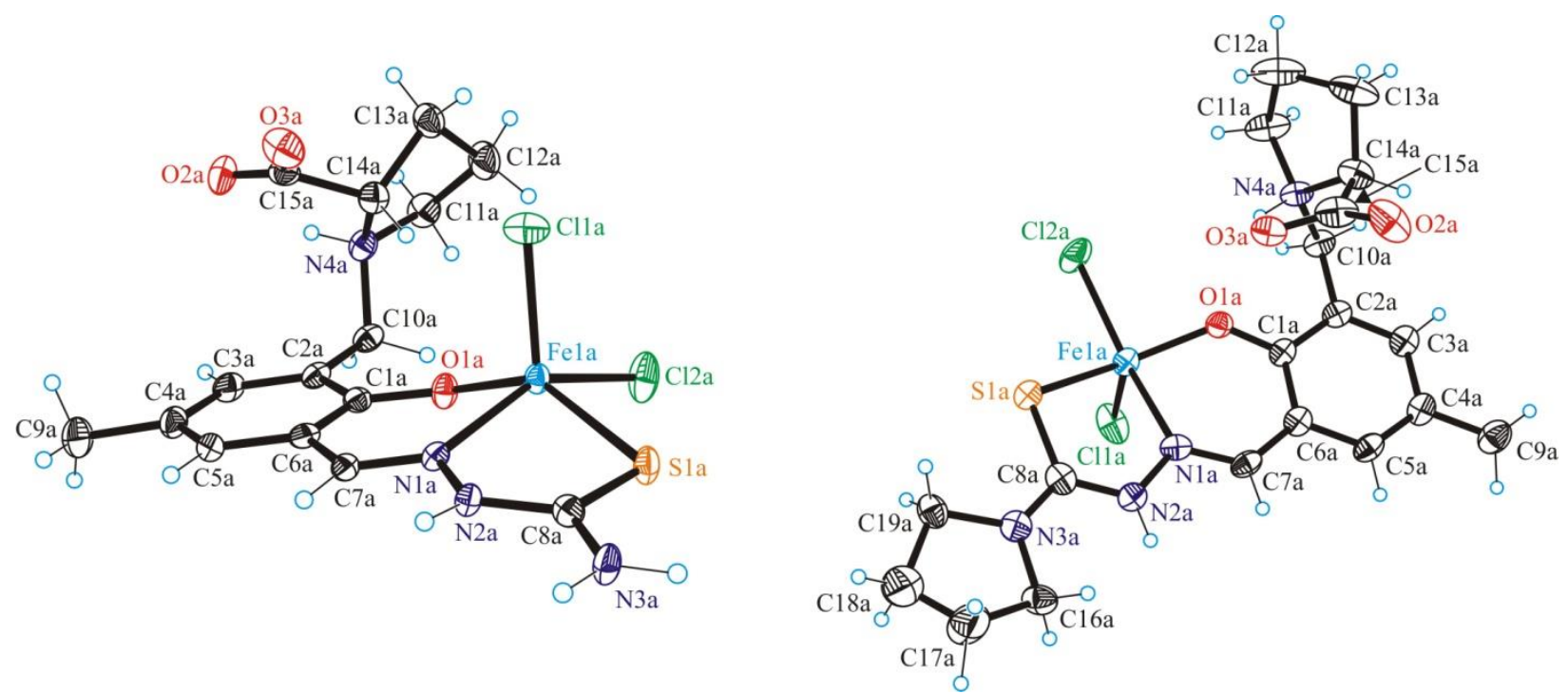

Figure 3. ORTEP views of 1 (left) and 2 (right) with atom labeling scheme; thermal ellipsoids were drawn at the $50 \%$ probability level. Selected bond distances $(\AA)$ and bond angles $\left({ }^{\circ}\right)$ in 1: Fe1a-O1a 1.878(2), Fe1a-N1a 2.193(2), Fe1a-S1a 2.3585(9), Fe1a-Cl1a 2.2245(8), Fe1a-Cl2a 2.2616(8), C1a-O1a 1.315(4), N1a-N2a 1.387(3), N2a-C8a 1.327(4), C8a-S1a 1.707(3), C8a-N3a 1.322(4); O1a-Fe1a-N1a 82.81(9), N1a-Fe1a-S1a 78.52(7); in 2: Fe1a-O1a 1.899(4), Fe1a-N1a 2.148(5), Fe1a-S1a 2.3769(17), Fe1a-Cl1a 2.2332(18), Fe1a-Cl2a 2.2473(19), C1a-O1a 1.311(7), N1a-N2a 1.383(7), N2a-C8a 1.335(8), C8a-S1a 1.726(7), C8a-N3a 1.307(8); O1a-Fe1a-N1a 84.00(19), N1a-Fe1a-S1a 78.70(15). The molecules of solvent were omitted for clarity.

The iron(III) atom comes out from the basal plane defined by donor atoms O1a, N1a, S1a and $\mathrm{Cl} 2 \mathrm{a}$ towards $\mathrm{Cl} 1 \mathrm{a}$ in 1 and 2 by 0.579 and $0.561 \AA$, respectively. In complexes 3 and $\mathbf{4}^{\prime}$ the ligands $\left(\mathrm{HL}^{3}\right)^{-}$and $\left(\mathrm{HL}^{4}\right)^{-}$are bound to iron(III) similarly. However, iron(III) in $\mathbf{3}$ and $\mathbf{4}$ ' adopts a distorted octahedral coordination geometry with one chlorido ligand and one molecule of solvent (methanol or $\mathrm{dmf}$ ) in axial positions, and another chlorido ligand, along with three donor atoms of the corresponding 
tridentate ligand occupying the equatorial coordination places as shown in Figure 4. The increase of coordination number in $\mathbf{3}$ and $\mathbf{4}^{\prime}$ is presumably due to the presence of electron-withdrawing substituents at terminal thioamide nitrogen atom of thiosemicarbazide moiety in both these complexes, which decreases the electron density on iron atom. As a result the affinity for a sixth ligand ( $\mathrm{MeOH}$ or $\mathrm{dmf}$ ) increases.
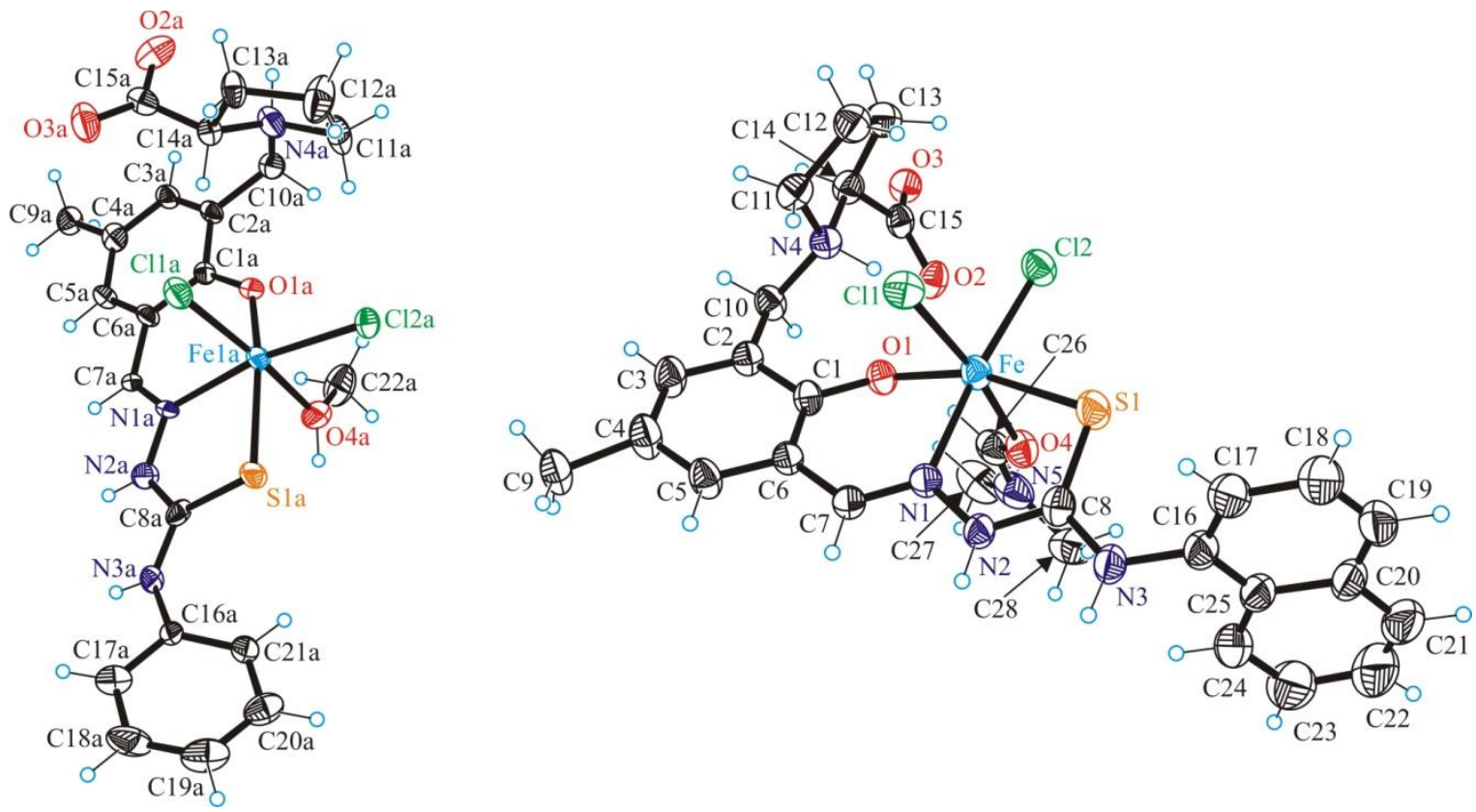

Figure 4. ORTEP view of 3 (left) and 4' (right) with atom labeling scheme; thermal ellipsoids were drawn at the 50 and $30 \%$ probability level, respectively. Selected bond distances $(\AA)$ and bond angles $\left(^{\circ}\right)$ in 3: Fe1a-O1a 1.896(2), Fe1a-N1a 2.188(6), Fe1a-S1a 2.431(2), Fe1a-Cl1a 2.333(2), Fe1a-Cl2a 2.303(2), Fe1a-O4a 2.182(6), C1a-O1a 1.307(9), N1a-N2a 1.379(8), N2a-C8a 1.338(9), C8a-S1a 1.709(8), C8a-N3a 1.333(9); O1a-Fe1a-N1a 86.7(2), N1a-Fe1a-S1a 78.85(16); in 4': Fe-O1 1.923(2), Fe-N1 2.178(3), Fe-S1 2.4167(10), Fe-Cl1 2.3633(11), Fe1-Cl2 2.2915(11), $\mathrm{Fe}-\mathrm{O} 4$ 2.101(4), C1-O1 1.320(4), N1-N2 1.380(4), N2-C8 1.347(5), C8-S1 1.701(4), C8-N3 1.328(5); O1-Fe-N1 84.36(10), N1-Fe-S1 80.02(8). The molecules of solvent were omitted for clarity.

The $\mathrm{Fe}-\mathrm{O}, \mathrm{Fe}-\mathrm{N}, \mathrm{Fe}-\mathrm{S}$ and $\mathrm{Fe}-\mathrm{Cl}$ bond lengths in $\mathbf{3}$ and 4' are markedly longer than those in a series of iron(III) complexes with 2-hydroxy-1-naphthaldehydethiosemicarbazones reported recently. ${ }^{24}$ This is probably due to the different 
coordination numbers in the two types of the compounds and reduced ligand-ligand repulsions in five-coordinate iron(III) complexes with 2-hydroxy-1-naphthaldehydethiosemicarbazones. ${ }^{24}$

The carboxylate group of the proline moiety is not coordinated to iron(III). Instead it is involved in formation of noncentrosymmetric dimeric associates via hydrogen bonds with nitrogen atoms of thiosemicarbazide fragment as shown in Figures S26-S29. Fivecoordinate and six-coordinate complexes $\mathbf{1}$ and $\mathbf{3}$ form dimeric associates via the same set of hydrogen bonds. Even though the formation of dimeric associates is also found in the crystal structure of $\mathbf{2}$ (Figure S27), a dissimilar type of hydrogen bonding involved is due to the absence of terminal nitrogen as proton donor as was the case for $\mathbf{1}$ and $\mathbf{3}$. In 4 ' the presence of bulky naphthyl group at terminal nitrogen proton donor precludes the formation of dimeric associates. Instead the molecules of 4' are building a 1D chain of $\mathrm{H}$-bonded molecules with a two molecule portion shown in Figure S29.

\section{Solution speciation and UV-vis measurements for monitoring the stability of} iron(III) complexes. The solution stability of the complexes 1-4 was investigated following the changes of UV-vis bands in the region of 200-700 nm in $\mathrm{MeOH}$ and in $\mathrm{MeOH} / \mathrm{H}_{2} \mathrm{O}$ (1:1) solutions. UV-vis spectra of methanolic solutions of $\mathbf{1 - 4}$ did not show marked changes of the solutions even after 7 days of standing at room temperature (Figures S20-S24). The compounds 1 and 2 were stable in $\mathrm{MeOH} / \mathrm{H}_{2} \mathrm{O}$ (1:1) over $15 \mathrm{~h}$, while the complex 3 underwent changes after $30 \mathrm{~min}$ in $\mathrm{MeOH} / \mathrm{H}_{2} \mathrm{O}$ (1:1) solution at room temperature. The formation of precipitate was observed after $15 \mathrm{~h}$ (Figures S30S32). These changes are partly due to the limited solubility of the complex $\mathbf{3}$ under the given conditions, although the spectral changes indicate some decomposition of the complex as well. The solution speciation of the iron(III) $-\mathrm{H}_{2} \mathbf{L}^{1}$ system was determined in a $30 \%(\mathrm{w} / \mathrm{w})$ dmso/ $\mathrm{H}_{2} \mathrm{O}$ mixture in our recent work ${ }^{18}$ via $\mathrm{pH}$-potentiometric and UVvis spectrophotometric titrations. Results revealed the formation of mono-ligand complexes such as $\left[\mathrm{Fe}\left(\mathrm{HL}^{1}\right)\right]^{2+},\left[\mathrm{Fe}\left(\mathbf{L}^{1}\right)\right]^{+}$, and bis-ligand complexes: $\left[\mathrm{Fe}\left(\mathrm{HL}^{1}\right)\left(\mathbf{L}^{1}\right)\right]$, $\left.\left[\mathrm{Fe}\left(\mathbf{L}^{1}\right)_{2}\right)\right]^{-}$and $\left[\mathrm{Fe}\left(\mathbf{L}^{1}\right)_{2}(\mathrm{OH})\right]^{2-}$. The protonated iron(III) complexes containing $\left(\mathrm{HL}^{1}\right)^{-}$are formed typically in the acidic $\mathrm{pH}$ range, and the stability of the bis-ligand complex 
$\left.\left[\mathrm{Fe}\left(\mathbf{L}^{1}\right)_{2}\right)\right]^{-}$is very high. As a consequence complex $\mathbf{1}$ with the originally $\left[\mathrm{Fe}\left(\mathrm{HL}^{1}\right)\right]^{2+}$ composition most probably has a different stoichiometry after dissolution in the aqueous solution. $\mathrm{pK} \mathrm{a}$ of this complex is $2.91 .{ }^{18}$ This indicates the complete deprotonation of the non-coordinating hydrazinic $\mathrm{N}^{2}-\mathrm{H}$ atom at $\mathrm{pH}>4.5$. This deprotonation is accompanied by significant spectral changes as shown in Figure S33. However, spectra remain practically unchanged at $\mathrm{pH}$ between $\sim 6$ and $\sim 10$ as a result of the formation of the $\left.\left[\mathrm{Fe}\left(\mathbf{L}^{1}\right)_{2}\right)\right]^{-}$complex even at 1:1 metal-to-ligand ratio. (Notably these spectra are fairly similar to those recorded at 1:2 metal-to-ligand ratio at $\mathrm{pH}$ between 6.8 and 9.8). ${ }^{18}$ On the basis of the reported stability constants concentration distribution curves were calculated for complex 1 (Figure 5), which suggest that the proligand is mostly bound in the bis-ligand complex $\left[\mathrm{Fe}\left(\mathbf{L}^{1}\right)_{2}\right]^{2+}$ at $\mathrm{pH} 7.4$ in solution. It should be also noted that the stability of the iron(III) complexes is significantly higher than that of the iron(II) species. ${ }^{18}$

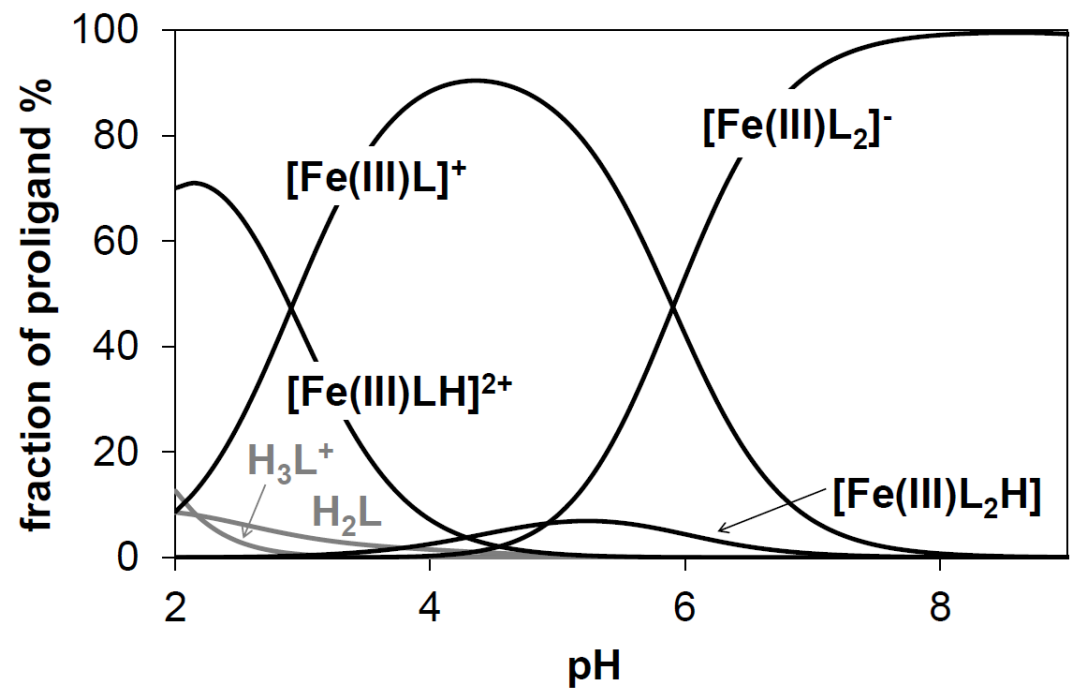

Figure 5. Concentration distribution curves for complex 1 in the $\mathrm{pH}$ range from 2 to 8 calculated on the basis of stability constants taken from ref.18. [ $\mathrm{C}_{\text {complex } 1}=1.0 \times 10^{-3}$ $\mathrm{M} ; \mathrm{T}=298 \mathrm{~K}, \mathrm{I}=0.10 \mathrm{M}(\mathrm{KCl})$ in $\left.30 \%(\mathrm{w} / \mathrm{w}) \mathrm{dmso} / \mathrm{H}_{2} \mathrm{O}\right]$.

Similar complexation processes and stoichiometry of the complexes are assumed for the other three proligands $\mathrm{H}_{2} \mathbf{L}^{2}-\mathrm{H}_{2} \mathrm{~L}^{4}$ as they coordinate in a similar manner, namely, via the $\mathrm{O}, \mathrm{N}, \mathrm{S}^{-}$donor set, but most likely the stability of the complexes somewhat differs due to the presence of different substituents at terminal nitrogen atom of thiosemicarbazide moiety. The substituents at the $\mathrm{N}$-terminal position are located quite close to the sulfur atom, which is involved in the coordination. The electron-donating 
methyl substituents have an unambiguous effect on the electron distribution in the thioamide moiety, thus on the coordination bond as well. In the case of the $\alpha-\mathrm{N}$-pyridyl thiosemicarbazones the increased stability of the iron(III/II) complexes by the N-terminal dimethylation is well documented in one of our previous papers. ${ }^{31}$ Based on the solution speciation data, the iron(III) complexes of salicylaldehyde (and $\alpha-\mathrm{N}$-pyridyl thiosemicarbazones) show a more favoured formation of bis-complexes over the mono species. As a consequence, at 1:1 metal-to-ligand ratio not only mono species are formed, but bis-complexes too. It results in the appearance of unbound iron(III) ions which tend to hydrolyze without the presence of other chelating agents. In the biological assays no precipitation occurred (or it was not visible) as the free iron(III) was most probably complexed by the components of the applied medium.

Magnetic susceptibility measurements. The temperature dependence of the magnetic susceptibility (XMT) for complexes 2 and $\mathbf{4}$ was measured and a Curie plot is shown in Figure S34. At room temperature, the XMT product is equal to $4.25 \mathrm{~mL} \mathrm{~K} \mathrm{~mol}^{-1}$ for 2 and $4.30 \mathrm{~mL} \mathrm{~K} \mathrm{~mol}^{-1}$ for $\mathbf{4}$. These values correspond well to the isolated high-spin iron(III) $(S=5 / 2)^{32}$ with isotropic $g$ values 1.97 and 1.98 for 2 and $\mathbf{4}$, respectively. At low temperature a sharp decrease of $X M T$ values is observed. Taking into account the mononuclear structure of $\mathbf{2}$ and $\mathbf{4}$ this behaviour is, presumably, due to the nonnegligible zero field splitting $(\mathrm{ZFS})^{33}$ of iron(III), as well as to the presence of intermolecular interactions in 2 and $\mathbf{4}$.

Electrochemistry. The electrochemical experiments on selected iron complexes were performed in $\mathrm{MeCN} / \mathrm{nBu}_{4} \mathrm{NPF}_{6}$ solution at platinum working electrode at scan rate of $100 \mathrm{mV} \mathrm{s}^{-1}$. As shown in Figure 6 the cathodic peak potential $E_{\mathrm{pc}}$ of iron(III)/iron(II) redox couple is $-0.87 \mathrm{~V},-0.80 \mathrm{~V}$, and $-0.78 \mathrm{~V}$ vs. $\mathrm{Fc}^{+} / \mathrm{Fc}(-0.23 \mathrm{~V},-0.16 \mathrm{~V}$, and -0.14 V vs. NHE) for 1-3, respectively. Complex 4 exhibits similar redox behaviour with that of 3 with the less negative cathodic peak potential at $-0.73 \mathrm{~V}$ vs. $\mathrm{Fc}^{+} / \mathrm{Fc}$ (see violet trace in Figure 6). However, we observed an additional reduction peak at even less negative peak potential of $-0.54 \mathrm{~V}$ indicating more complex redox behaviour. 


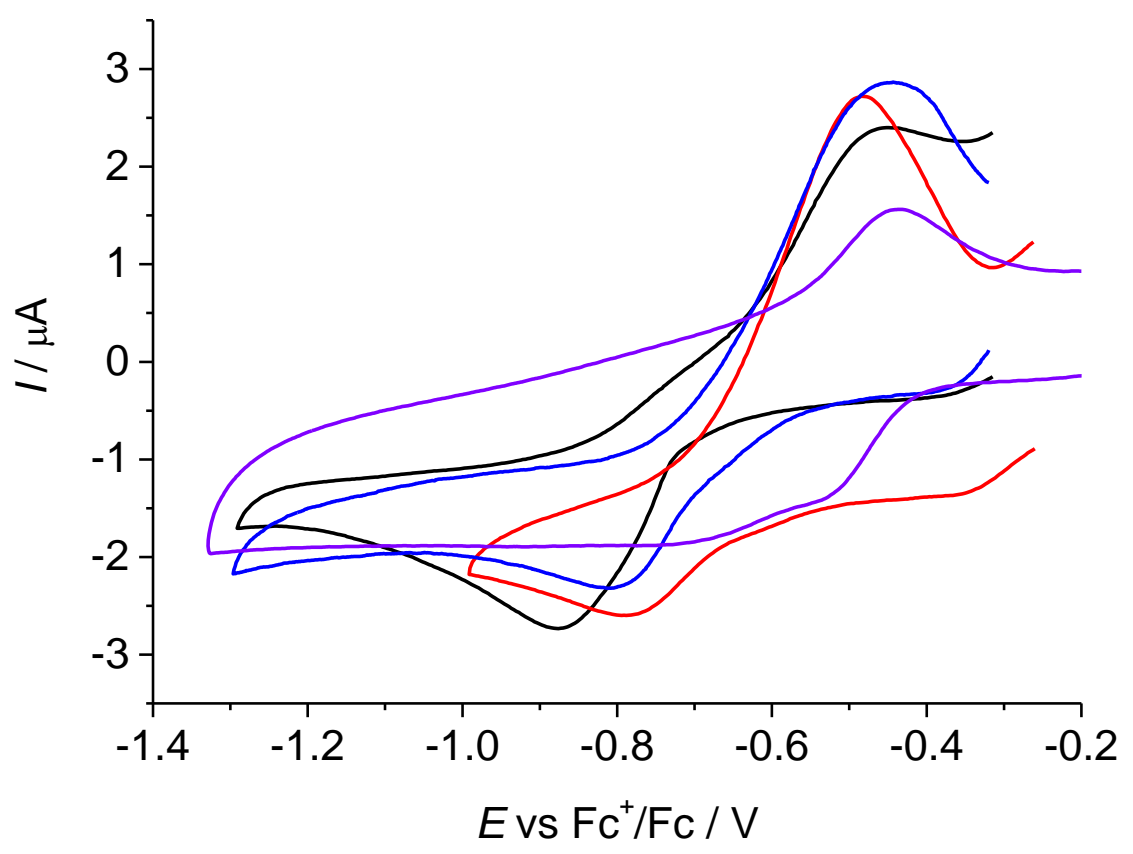

Figure 6. The cyclic voltammograms of $0.5 \mathrm{mM}$ of 1 (black trace), 2 (blue trace), 3 (red

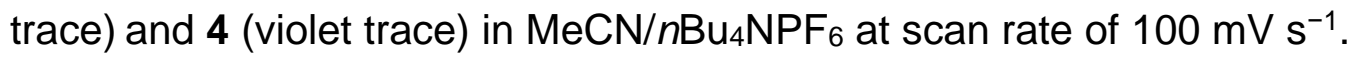

The corresponding cyclic voltammograms showed one reduction peak with a strongly shifted reoxidation peak (peak-to-peak separation around $400 \mathrm{mV}$ ) exhibiting typical features of a slow electron process. The shape of the cyclic voltammograms in the reverse scan additionally indicates a weakly adsorbed reduction product, where a desorption characteristic for redissolution of presumably less soluble iron(II) species upon reoxidation to iron(III) state occurs. Therefore, for simulation of the corresponding cyclic voltammograms a small rate constant for the heterogeneous electron transfer was used $\left(k_{\mathrm{s}}=2.5 \times 10^{-4} \mathrm{~cm} \mathrm{~s}^{-1}\right.$ for $1, k_{\mathrm{s}}=1 \times 10^{-3} \mathrm{~cm} \mathrm{~s}^{-1}$ for 2 and $k_{\mathrm{s}}=5 \times 10^{-4} \mathrm{~cm} \mathrm{~s}^{-1}$ for 3). As shown in Figure $S 35$ a fairly good fit was achieved taking into account additionally the adsorption of the reduced species on the electrode surface $(\Gamma \max =5 \times$ $10^{-6}, 1 \times 10^{-5}$ and $8 \times 10^{-6}$ for $\mathbf{1}^{-}, \mathbf{2}^{-}$and $\mathbf{3}^{-}$respectively) providing further evidence for adsorption processes. The simulation enabled us to determine the formal redox potentials for investigated iron complexes $\left(E^{0,}=-0.67 \vee\right.$ for $1,-0.65 \vee$ for 2 and $0.65 \mathrm{~V}$ for 3 , all vs. $\mathrm{Fc}^{+} / \mathrm{Fc}$ ). These low redox potentials clearly occur within the 
biologically accessible window ( -0.4 to $+0.8 \mathrm{~V}$ vs. NHE) using the known $E_{1 / 2}$ of ferrocene $(+0.64 \mathrm{~V})$ vs. Standard Hydrogen Electrode $(\mathrm{SHE}){ }^{34}$ These results are comparable with those reported for other iron(III)-TSC complexes. ${ }^{35,36}$ Such redox active complexes are able to markedly increase the amount of ROS in cancer cells. Hydroxyl radicals in such systems can be obtained from Fenton reactions, where the iron cycles between the Fe(II) and Fe(III) oxidation states.

Cytotoxicity. Cytotoxic potential of the hybrids $\mathrm{H}_{2} \mathrm{~L}^{1}-\mathrm{H}_{2} \mathrm{~L}^{4}$ and four iron(III) complexes 1-4 was investigated in five human and one murine cancer cell lines, namely HeLa, FemX, A549, LS-174, MDA-MB-453 and MS1, as well as in one noncancerous cell line MRC- 5 by means of the colorimetric MTT assay. The derivatives $H_{2} L^{1}-H_{2} L^{4}$ and their iron(III) complexes $1-4$ show $\mathrm{IC}_{50}$ values in the range from 14.7 to $>300 \mu \mathrm{M}$ (Table 2). None of the compounds tested has reached the level of cytotoxicity of cisplatin on investigated cancer cell lines. The following structure-activity relationships were established: (i) the impact of substitution at terminal $\mathrm{NH}_{2}$ group of TSC moiety, (ii) impact of metal coordination of the hybrids and (iii) metal identity.

Substitution at the terminal $\mathbf{N}$ atom of the TSC moiety. The favourable effect of terminal $\mathrm{N}$ atom substitution of the hybrid $\mathrm{H}_{2} \mathrm{~L}^{1}$ by pyrrolidinyl group in $\mathrm{H}_{2} \mathrm{~L}^{2}$, phenyl group in $\mathrm{H}_{2} \mathrm{~L}^{3}$ and naphthyl group in $\mathrm{H}_{2} \mathrm{~L}^{4}$ was observed by increase of the cytotoxic potency in the following order: $\mathrm{H}_{2} \mathrm{~L}^{1}<\mathrm{H}_{2} \mathrm{~L}^{2}<\mathrm{H}_{2} \mathrm{~L}^{3}<\mathrm{H}_{2} \mathrm{~L}^{4}$ in all cancer cell lines except LS-174. In the latter, the rank order was $H_{2} L^{1}<H_{2} L^{2}<H_{2} L^{4}<H_{2} L^{3}$. $H_{2} L^{2}$ showed slightly better activity compared to $\mathbf{H}_{2} \mathbf{L}^{1}$ in all cancer cell lines. The substitution with aromatic groups (hybrids $\mathrm{H}_{2} \mathrm{~L}^{3}$ and $\mathrm{H}_{2} \mathrm{~L}^{4}$ ) resulted in a 2- to more than 20 -fold increase of cytotoxic potency of the hybrids in all cancer cell lines. Cancer cell lines FemX and MS1 were most sensitive to substitution of one $\mathrm{H}$ atom at terminal $\mathrm{NH}_{2}$ of TSC moiety by naphthyl group (hybrid $\mathbf{H}_{2} \mathrm{~L}^{4}$ ). I $\mathrm{C}_{50}$ values of $15 \mu \mathrm{M}$ in FemX and $20 \mu \mathrm{M}$ in MS1 cell lines, indicate ca. 20- and 15-fold increase of cytotoxicity compared to $\mathbf{H}_{2} \mathbf{L}^{1}$. 
Table 2. $I_{50}$ values after inhibition of cell growth by the hybrids $H_{2} L^{1}-H_{2} L^{4}$ and complexes 1-4 in six cancer cell lines (A549, FemX, HeLa, LS-174, MDA-MB-453 and MS1) and noncancerous cell line (MRC-5).

\begin{tabular}{|c|c|c|c|c|c|c|c|}
\hline \multicolumn{8}{|c|}{$\overline{\left.I C_{50}, \mu \mathrm{M} \text { (value } \pm S D\right)^{[a]}}$} \\
\hline & A549 & FemX & HeLa & LS-174 & $\begin{array}{c}\text { MDA- } \\
\text { MB-453 }\end{array}$ & MS1 & MRC-5 \\
\hline $\mathrm{H}_{2} \mathrm{~L}^{1}$ & $>300^{[b]}$ & $>300^{[b]}$ & $>300^{[b]}$ & $>300^{[b]}$ & $>300^{[b]}$ & $>300^{[b]}$ & $>300^{[b]}$ \\
\hline $\mathrm{H}_{2} \mathrm{~L}^{2}$ & $271 \pm 11$ & $221 \pm 12$ & $240 \pm 5$ & $295 \pm 0$ & $>300^{[b]}$ & $207 \pm 4$ & $203 \pm 2$ \\
\hline $\mathrm{H}_{2} \mathrm{~L}^{3}$ & $141 \pm 4$ & $31 \pm 2$ & $146 \pm 7$ & $48 \pm 3$ & $>300^{[b]}$ & $125 \pm 8$ & $211 \pm 9$ \\
\hline $\mathrm{H}_{2} \mathrm{~L}^{4}$ & $212 \pm 1$ & $15 \pm 2$ & $120 \pm 7$ & $135 \pm 3$ & $109 \pm 1$ & $20 \pm 3$ & $204 \pm 10$ \\
\hline 1 & $51 \pm 7$ & $53 \pm 3$ & $61 \pm 3$ & $91 \pm 6$ & $39 \pm 1$ & $44 \pm 3$ & $26 \pm 2$ \\
\hline 2 & $53 \pm 3$ & $25 \pm 5$ & $57 \pm 2$ & $60 \pm 7$ & $28 \pm 1$ & $33 \pm 1$ & $41 \pm 2$ \\
\hline 3 & $72 \pm 1$ & $54 \pm 2$ & $52 \pm 4$ & $87 \pm 3$ & $40 \pm 1$ & $39 \pm 3$ & $52 \pm 3$ \\
\hline 4 & $78 \pm 9$ & $24 \pm 1$ & $78 \pm 8$ & $89 \pm 5$ & $66 \pm 0$ & $25 \pm 0$ & $24 \pm 1$ \\
\hline cisplatin $^{[c]}$ & $17 \pm 1^{[c]}$ & $11 \pm 1$ & $8 \pm 2^{[c]}$ & $22 \pm 7$ & $21 \pm 6$ & n.d. & $30 \pm 3^{[c]}$ \\
\hline
\end{tabular}

[a] IC50 values were calculated as mean values obtained from three independent experiments after $48 \mathrm{~h}$ of cell exposure in the MTT assay. $\mathrm{IC}_{50}$ values are quoted with their standard deviations (SD). [b] The sign > indicates that $\mathrm{IC}_{50}$ value is not reached in the examined range of concentrations. [c] $\mathrm{IC}_{50}$ values for cisplatin were taken from ref. 37. The tested compounds were applied at the following concentrations: $18.75 ; 37.5 ; 75$; $150 ; 300 \mu \mathrm{M})$.

In the cell line MDA-MB-453 the positive effects of ligand substitution and metal coordination are also obvious. Introduction of naphthyl group increased the cytotoxicity, while coordination to iron enhanced it by a factor of 2 . According to $\mathrm{IC}_{50}$ values, introduction of naphthyl group increased the cytotoxicity of $\mathbf{H}_{2} \mathbf{L}^{1}$ by ca. 3 times, whereas coordination to iron improved the cytotoxicity of $\mathbf{H}_{2} \mathbf{L}^{1}$ by ca. 8 times (complex $\mathbf{1}$ ).

Notably, $\mathrm{H}_{2} \mathbf{L}^{\mathbf{1}}$ is mainly present in $\mathrm{H}_{2} \mathbf{L}(75 \%)$ and $\mathrm{HL}^{-}(25 \%)$ forms in aqueous solution at $\mathrm{pH} 7.4$ based on its $\mathrm{pK}_{\mathrm{a}}$ values. ${ }^{18} \mathrm{H}_{2} \mathrm{~L}$ has zwitter ionic structure containing negatively charged carboxylate and protonated proline nitrogen moieties, and $\mathrm{HL}^{-}$is formed by the 
deprotonation of the phenolic $\mathrm{OH}$ group. In all, these features strongly contribute to the relatively high hydrophilicity of the compound $\mathrm{H}_{2} \mathrm{~L}^{1}\left(\log D_{7.4}=-0.56\right) .{ }^{18}$ Its derivatives $\mathrm{H}_{2} \mathrm{~L}^{3}$ and $\mathrm{H}_{2} \mathrm{~L}^{4}$ are most probably more lipophilic due to the presence of the phenyl and naphthyl groups, what is advantageous for the easier passage via the biological membranes resulting in the increased cytotoxicity. The drug delivery and activity of the iron complexes might be improved by attaching them to a prodrug carrier as recently published for a series of related iron complexes. ${ }^{24}$ All those iron complexes possess one tridendate Schiff-base ligand (modified just at terminal $\mathrm{N}$-atom), one iron centre and two chloride ligands (as leaving groups). ${ }^{24}$

Metal coordination. Iron(III) complexes $\mathbf{1}$ and $\mathbf{2}$ showed an improved antiproliferative activity compared to their corresponding metal-free ligands in all cancer cell lines, which may be a consequence of the altered size, lipophilicity and charge upon complex formation. The strongest effect of iron coordination on cytotoxicity (ca. 9 fold increase) compared to the corresponding metal-free ligand, was observed for $\mathbf{2}$ in FemX cell line. On the other hand, coordination of the hybrids with aromatic substituents $\left(\mathrm{H}_{2} \mathrm{~L}^{3}\right.$ and $\mathbf{H}_{2} \mathrm{~L}^{4}$ ) to iron in $\mathbf{3}$ and $\mathbf{4}$ showed mixed results with increase of cytotoxic activity in HeLa, A549 and MDA-MB-453 cell lines and reduction of cytotoxic activity in MS1, LS-174 and FemX. According to IC 50 values, an improved cytotoxic activity of iron(III) complexes towards investigated cell lines, could be attributed to their contribution to ROS generation, as previously reported, ${ }^{23,35}$ in addition to increasing of their lipophilicity by introduction of bulky aromatic groups.

Metal identity. The coordination of $\mathrm{H}_{2} \mathrm{~L}^{2}$ to iron(III) increases the antiproliferative activity by a factor of 5 in A549 cell lines what is comparable with recently reported results for the same hybrid and its nickel(II), palladium(II) and copper(II) mono-ligand complexes. ${ }^{28}$ The coordination to nickel(II) and palladium(II) led to a drop of cytotoxic potency of $\mathbf{H}_{2} \mathrm{~L}^{2}$, while coordination to copper increased it by a factor 9.5. Taking together, the following order of cytotoxic activity could be presented for nickel(II), palladium(II), copper(II) and iron(III) complexes of $\mathbf{H}_{2} \mathrm{~L}^{2}$ of $1: 1$ stoichiometry in $\mathrm{A} 549$ cancer cell lines: $\mathrm{Ni}(\mathrm{II})<\mathrm{Pd}(\mathrm{II})<$ $\mathrm{H}_{2} \mathrm{~L}^{2}<\mathrm{Fe}(\mathrm{III})(5$ fold $)<\mathrm{Cu}$ (II) $(9.5$ fold $)$. 
Selectivity. Comparing the $\mathrm{IC}_{50}$ values measured in the tested cancerous and the noncancerous cell lines it can be concluded that all compounds showed poor selectivity or no selectivity to cancer cell lines. The proligands $\mathrm{H}_{2} \mathrm{~L}^{3}$ and $\mathrm{H}_{2} \mathrm{~L}^{4}$, possess slightly better selectivity to cancer cells compared to their corresponding iron(III) complexes, where the selectivity is absent.

\section{Conclusions}

Two hybrids $\mathrm{H}_{2} \mathrm{~L}^{3}$ and $\mathrm{H}_{2} \mathrm{~L}^{4}$, and five iron(III) complexes 1-4 and 4' were synthesised, characterised by spectroscopic, ESI-MS and magnetic susceptibility methods and their antiproliferative activity against six human and murine cancer cell lines and one normal cell line was studied. The substitution at the terminal $\mathrm{NH}_{2}$ group of the TSC moiety of the hybrids induces positive cytotoxic effect, which may be attributed to their hydrophilicity/lipophilicity balance.

Iron(III) complexes were isolated in solid state and their structure was confirmed by Xray diffraction measurements, mass spectrometry and elemental analysis. Attachment of aromatic groups to terminal $\mathrm{N}$ atom of TSC moiety favours octahedral coordination geometry of central iron atom, while introduction of aliphatic groups induces squarepyramidal coordination geometry, which is attributed to electron-withdrawing or electrondonating effect of the substituents at the terminal $\mathrm{N}$ atom of TSC moiety of the hybrids, respectively. Thus, the hybrids $\mathrm{H}_{2} \mathrm{~L}^{1}$ and $\mathrm{H}_{2} \mathrm{~L}^{2}$ with iron(III) form square-pyramidal complexes $\left[\mathrm{Fe}\left(\mathrm{HL}^{1}\right) \mathrm{Cl}_{2}\right]$ (1) and $\left[\mathrm{Fe}\left(\mathrm{HL}^{2}\right) \mathrm{Cl}_{2}\right] \cdot 1.6 \mathrm{H}_{2} \mathrm{O}$ (2), while $\mathrm{H}_{2} \mathrm{~L}^{3}$ and $\mathrm{H}_{2} \mathrm{~L}^{4}$ octahedral complexes $\left[\mathrm{Fe}\left(\mathrm{HL}^{3}\right)(\mathrm{MeOH}) \mathrm{Cl}_{2}\right] \cdot 0.5 \mathrm{H}_{2} \mathrm{O} \quad$ (3) and $\left[\mathrm{Fe}\left(\mathrm{HL}^{4}\right)(\mathrm{dmf}) \mathrm{Cl}_{2}\right] \cdot 0.5 \mathrm{Et}_{2} \mathrm{O} \cdot \mathrm{H}_{2} \mathrm{O}\left(4^{\prime}\right)$. However, these differences observed in the solid state are not characteristic for their behaviour in solution. Instead, favoured formation of bis-ligand iron(III) complexes is observed, in addition to mono-ligand complexes, at physiological $\mathrm{pH}$.

The substitution at the terminal $\mathrm{NH}_{2}$ group of TSC moiety of $\mathbf{H}_{2} \mathbf{L}^{1}$ by pyrrolydinyl, phenyl, and naphthyl group enhances the antiproliferative activity of all hybrids in all investigated cancer cell lines with exception of colon cancer cell line (LS-174) where the cytotoxicity follows the order $\mathbf{H}_{2} \mathbf{L}^{1}<\mathrm{H}_{2} \mathrm{~L}^{2}<\mathrm{H}_{2} \mathrm{~L}^{4}<\mathrm{H}_{2} \mathrm{~L}^{3}$. Iron(III) complexes 1-4 showed 
better cytotoxic potency compared to their corresponding hybrids with exception of complex $\mathbf{3}$ in LS-174 cell line, complex 4 in MS1 cell line and complexes $\mathbf{3}$ and $\mathbf{4}$ in FemX, where they showed reduced cytotoxicity compared to their parent hybrids. On the other hand, neither hybrids nor complexes displayed significant selectivity toward cancerous cells over normal cells. In general, structural modification at terminal $\mathrm{N}$ atom of TSC moiety of the hybrids, especially by introducing aromatic groups, has significant impact on cytotoxicity. Metal coordination causes beneficial effects on cytotoxic activity, particularly in the case of essential transition metals (iron and copper). Metal identity affects the cytotoxic potency of the hybrids in agreement to our previous work in such a manner, that essential metals (iron and copper) improve cytotoxicity of the metal-free ligands, while other transition metals ( $\mathrm{Ni}$ and $\mathrm{Pd}$ ) reduce it.

\section{Experimental section}

Chemicals. All reagents were used as purchased from commercial suppliers. 4-Phenyl3-thiosemicarbazide and 1-isothiocyanatonaphthalene were purchased from Sigma Aldrich, L-proline from Alfa Aesar and $\mathrm{FeCl}_{3} \cdot 6 \mathrm{H}_{2} \mathrm{O}$ from Riedel-de-Haën. 4-(1Naphthyl)-3-thiosemicarbazide was synthesised as described in the literature with $30 \%$ yield. ${ }^{38}$

\section{Synthesis of proligands}

The synthesis of $\mathrm{H}_{2} \mathrm{~L}^{1} \cdot \mathbf{1 . 5} \mathrm{H}_{2} \mathrm{O}$ was previously reported. ${ }^{18}$ 2-Hydoxy-3-methyl-(S)pyrrolidine-2-carboxylate-5-methylbenzaldehyde (L-Pro-MSA) was prepared in 34\% yield, starting from L-proline instead of methyl L-proline ester hydrochloride. The reaction product was purified by column chromatography using $\mathrm{MeOH} / \mathrm{CHCl}_{3}(1: 25)$ as eluent. $\mathrm{H}_{2} \mathrm{~L}^{2} \cdot 2 \mathrm{H}_{2} \mathrm{O}$ was synthesised by following a previously published procedure. ${ }^{28}$

$\mathrm{H}_{2} \mathrm{~L}^{3} \cdot 2 \mathrm{H}_{2} \mathrm{O}$. To a solution of L-Pro-MSA $(740 \mathrm{mg}, 2.82 \mathrm{mmol})$ in ethanol $(5 \mathrm{~mL})$ under stirring was added a solution of 4-phenyl-3-thiosemicarbazide (470 mg, $2.82 \mathrm{mmol}$ ) in water $(5 \mathrm{~mL})$. The reaction mixture was refluxed at $85^{\circ} \mathrm{C}$ for $30 \mathrm{~min}$ and then cooled to room temperature and allowed to stand at $5{ }^{\circ} \mathrm{C}$ overnight. The precipitate was filtered 
off, washed with cold $\mathrm{EtOH} / \mathrm{H}_{2} \mathrm{O}(1: 1)$ and dried in vacuo. Yield: $0.70 \mathrm{~g}, 64.0 \%$. Anal. Calc. for $\mathrm{C}_{21} \mathrm{H}_{24} \mathrm{~N}_{4} \mathrm{O}_{3} \mathrm{~S} \cdot 2 \mathrm{H}_{2} \mathrm{O}\left(\mathrm{Mr}_{\mathrm{r}}\right.$ 448.54): C 56.29, H 6.30, N 12.49, S 7.15; Found: C 56.45, H 5.87, N 12.62, S 7.18. ${ }^{1} \mathrm{H}$ NMR $\left(500 \mathrm{MHz},\left(\mathrm{CD}_{3}\right)_{2} \mathrm{SO}, 25^{\circ} \mathrm{C}\right): \delta 11.82(\mathrm{~s}, 1 \mathrm{H}$, $\mathrm{C}=\mathrm{N}-\mathrm{NH}), 11.62\left(\mathrm{~s}, 1 \mathrm{H}, \mathrm{Cph}_{\mathrm{ph}} \mathrm{OH}\right), 10.03$ (s, 1H, HN-Cph), 8.51 (s, 1H, HC=N), 7.88 (s, $1 \mathrm{H}, \mathrm{C}^{6} \mathrm{H}$ ), $7.58\left(\mathrm{~d}, 2 \mathrm{H} J=7.7 \mathrm{~Hz}, \mathrm{C}^{14} \mathrm{H}\right), 7.38\left(\mathrm{t}, 2 \mathrm{H}, J=7.7 \mathrm{~Hz}, \mathrm{C}^{15} \mathrm{H}\right), 7.22$ (t, 2H, $J=$ $\left.7.7 \mathrm{~Hz}, \mathrm{C}^{16} \mathrm{H}\right) 6.98\left(\mathrm{~s}, 1 \mathrm{H}, \mathrm{C}^{4} \mathrm{H}\right), 4.16\left(\mathrm{~d}, 1 \mathrm{H}, J=13.33 \mathrm{~Hz}, \mathrm{CH}_{2}\right), 3.52(\mathrm{~d}, 1 \mathrm{H}, J=13.33$ $\mathrm{Hz}, \mathrm{CH}_{2}$ peak partial overlapped with $\mathrm{DHO}$ proton signal), 2.91 (br. $\mathrm{s}, 1 \mathrm{H}$, proline), 2.43 (br. s, $1 \mathrm{H}$, proline), 2.29-2.19 (m, $1 \mathrm{H}$, proline), $2.23\left(\mathrm{~s}, 3 \mathrm{H}, \mathrm{CH}_{3}\right), 1.93-1.80(\mathrm{~m}, 2 \mathrm{H}$, proline), $1.77-1.67(\mathrm{~m}, 1 \mathrm{H}$, proline $) .{ }^{13} \mathrm{C}\left\{{ }^{1} \mathrm{H}\right\} \mathrm{NMR}\left(126 \mathrm{MHz},\left(\mathrm{CD}_{3}\right)_{2} \mathrm{SO}, 25{ }^{\circ} \mathrm{C}\right): \delta$ $\left.178.23(\mathbf{C}=\mathrm{S}), \quad 174.96\left(\mathbf{C O}_{2}\right)^{-}\right), 154.82\left(\mathbf{C}_{\mathrm{Ph}}-\mathrm{OH}\right), 140.23(\mathrm{HC}=\mathrm{N}), 136.66\left(\mathbf{C}^{13}\right)$

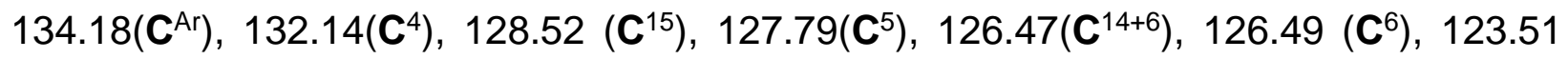
$\left(\mathbf{C}^{3}\right), 120.41\left(\mathrm{C}^{1}\right), 65.63(\mathrm{CH}$, proline $), 56.41\left(\mathrm{CH}_{2}(8)\right)$, $53.08\left(\mathrm{CH}_{2}\right.$, proline $), 29.46\left(\mathrm{CH}_{2}\right.$, proline), $23.47\left(\mathrm{CH}_{2}\right.$, proline), $20.55\left(\mathbf{C}^{7} \mathrm{H}_{3}\right)$. ESI-MS in $\mathrm{MeOH}$ (positive): $\mathrm{m} / z 413\left(\left[\mathrm{H}_{2} \mathrm{~L}^{3}\right.\right.$ $\left.+\mathrm{H}]^{+}\right)$. ESI-MS in $\mathrm{MeOH}$ (negative): $\mathrm{m} / z 411\left(\left[\mathrm{HL}^{3}\right]^{-}\right)$. UV-vis in $\mathrm{MeOH}, \lambda, \mathrm{nm}(\varepsilon$, $\mathrm{M}^{-1} \mathrm{~cm}^{-1}$ ) 219 (19 891) 340 (19859) 310 (18500). IR (ATR, selected bands, $V_{\max }, \mathrm{cm}^{-1}$ ) $3611,3440,3258,3208,2986,2859,2322,1618,1549,1471,1386,1314,1265,1223$, 1156, 1050, 757, 706 .

$\mathrm{H}_{2} \mathrm{~L}^{4} \cdot 2 \mathrm{H}_{2} \mathrm{O}$. To a solution of L-Pro-MSA $(0.72 \mathrm{~g}, 2.74 \mathrm{mmol})$ in ethanol $(20 \mathrm{~mL})$ a solution of $\mathrm{N}$-(naphthalen-1-yl)hydrazinecarbothioamide $(0.59 \mathrm{~g}, 2.74 \mathrm{mmol})$ in ethanol $(5 \mathrm{~mL})$ was added. The reaction mixture was refluxed at $85^{\circ} \mathrm{C}$ for $30 \mathrm{~min}$. The solvent was evapourated under reduced pressure and the remaining solution $(3 \mathrm{~mL})$ was allowed to stand at $5{ }^{\circ} \mathrm{C}$ overnight. The precipitate was filtered off, washed with cold ethanol and dried in vacuo. Yield: $1.26 \mathrm{~g}, 65.0 \%$. Anal. Calc. for $\mathrm{C}_{25} \mathrm{H}_{26} \mathrm{~N}_{4} \mathrm{O}_{3} \mathrm{~S} \cdot 2 \mathrm{H}_{2} \mathrm{O}(\mathrm{Mr}$ 498.60): C 60.22, H 6.06, N 11.24, S 6.43; Found: C 60.58, H 5.76, N 11.13, S 6.35. ${ }^{1} \mathrm{H}$ NMR $\left(500 \mathrm{MHz},\left(\mathrm{CD}_{3}\right)_{2} \mathrm{SO}, 25^{\circ} \mathrm{C}\right) \delta 11.92(\mathrm{~s}, 1 \mathrm{H}, \mathrm{C}=\mathrm{N}-\mathrm{NH}), 11.53(\mathrm{~s}, 1 \mathrm{H}, \mathrm{Cph}-\mathrm{OH})$, $10.31\left(\mathrm{~s}, 1 \mathrm{H}, \mathrm{HN}-\mathrm{C}_{\mathrm{Ph}}\right), 8.57(\mathrm{~s}, 1 \mathrm{H}, \mathrm{HC}=\mathrm{N}), 8.00-7.87(\mathrm{~m}, 7 \mathrm{H} \mathrm{Ar}), 7.94\left(\mathrm{~s}, 1 \mathrm{H}, \mathrm{C}^{6} \mathrm{H}\right)$, $6.97\left(\mathrm{~s}, 1 \mathrm{H}, \mathrm{C}^{4} \mathrm{H}\right), 4.17\left(\mathrm{~d}, 1 \mathrm{H}, J=13.36 \mathrm{~Hz}, \mathrm{CH}_{2}\right), 3.49\left(\mathrm{~d}, 1 \mathrm{H}, J=13.36 \mathrm{~Hz}, \mathrm{CH}_{2}\right.$ peak overlapped with DHO proton signal), $3.37(\mathrm{~m}, 1 \mathrm{H}$, proline peak overlapped with DHO proton signal), 2.94-2.88 ( $\mathrm{m}, 1 \mathrm{H}$, proline), 2.55-2.35 ( $\mathrm{m}, 1 \mathrm{H}$, proline), 2.25-2.15 $(\mathrm{m}, 1 \mathrm{H}$, proline), $2.20\left(\mathrm{~s}, 3 \mathrm{H}, \mathrm{CH}_{3}\right), 1.95-1.80(\mathrm{~m}, 2 \mathrm{H}$, proline), 1.75-1.65 (m, $1 \mathrm{H}$, proline), 
${ }^{13} \mathrm{C}\left\{{ }^{1} \mathrm{H}\right\}$ NMR $\left(126 \mathrm{MHz},\left(\mathrm{CD}_{3}\right)_{2} \mathrm{SO}, 25^{\circ} \mathrm{C}\right) \delta 178.07(\mathbf{C}=\mathrm{S}), 175.10\left(\mathrm{CO}_{2}^{-}\right), 154.82\left(\mathbf{C}_{\mathrm{Ph}}-\right.$ $\mathrm{OH}), 139.99(\mathrm{HC}=\mathrm{N}), 136.33\left(\mathbf{C}^{\mathrm{Ar}}\right), 134.18\left(\mathbf{C}^{\mathrm{Ar}}\right), 132.00\left(\mathbf{C}^{4}\right), 131.20\left(\mathbf{C}^{\mathrm{Ar}}\right), 127.72\left(\mathbf{C}^{\mathrm{Ar}}\right)$,

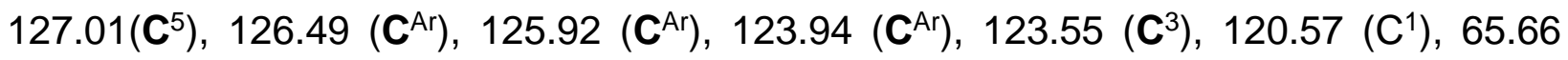
$\left(\mathrm{CH}\right.$, proline), $56.46\left(\mathrm{CH}_{2}(8)\right), 53.05\left(\mathrm{CH}_{2}\right.$, proline $), 29.48\left(\mathrm{CH}_{2}\right.$, proline $), 23.47\left(\mathrm{CH}_{2}\right.$, proline), $20.54\left(\mathrm{C}^{7} \mathrm{H}_{3}\right)$. ESI-MS in $\mathrm{MeOH}$ (positive): $\mathrm{m} / z 485\left(\left[\mathrm{H}_{2} \mathrm{~L}^{4}+\mathrm{Na}\right]^{+}\right)$. ESI-MS in $\mathrm{MeOH}$ (negative): $m / z 461$ ([ $\left.\left.\mathrm{H}_{2} \mathrm{~L}^{4}\right]^{-}\right)$. UV-vis in $\mathrm{MeOH}, \lambda, \mathrm{nm}\left(\varepsilon, \mathrm{M}^{-1} \mathrm{~cm}^{-1}\right) 222$ (46523) 340 (18611) 306 (17440). IR (ATR, selected bands, $v_{\max }, \mathrm{cm}^{-1}$ ) 3612, 3431, 3223, 3018, 2874, 2321, 1622, 1543, 1468, 1390, 1310, 1272, 1159, 1050, 1008, 975, 893, 859, $776,730,701$.

\section{Synthesis of iron(III) complexes}

[ $\mathrm{Fe}\left(\mathrm{HL}^{1}\right) \mathrm{Cl}_{2}$ ] (1). To a solution of $\mathrm{H}_{2} \mathrm{~L}^{1} \cdot 1.5 \mathrm{H}_{2} \mathrm{O}(0.05 \mathrm{~g}, 0.14 \mathrm{mmol})$ in methanol (55 mL) under stirring, a solution of $\mathrm{FeCl}_{3} \cdot 6 \mathrm{H}_{2} \mathrm{O}(0.05 \mathrm{~g}, 0.18 \mathrm{mmol})$ in methanol $(2 \mathrm{~mL})$ was added, and the reaction mixture was refluxed for $1.5 \mathrm{~h}$. After cooling to room temperature the solvent was evapourated under reduced pressure to ca. $5-10 \mathrm{~mL}$. Xray diffraction quality crystals were obtained by vapour diffusion of diethyl ether into the concentrated reaction mixture. These were washed with diethyl ether $(5 \mathrm{~mL})$ and dried in vacuo overnight. Yield: $0.02 \mathrm{~g}, 25.0 \%$. Anal. Calc. for $\mathrm{C}_{15} \mathrm{H}_{19} \mathrm{Cl}_{2} \mathrm{FeN}_{4} \mathrm{O}_{3} \mathrm{~S}\left(\mathrm{Mr}_{\mathrm{r}} 462.15\right)$ : C 38.98, H 4.14, N 12.12, S 6.94; Found: C 39.20, H 4.19, N 12.24, S 6.73. ESI-MS in $\mathrm{MeOH}$ (negative): $\mathrm{m} / \mathrm{z} 459$ ([Fe( $\left.\left.\left.\mathrm{L}^{1}\right) \mathrm{Cl}_{2}\right]^{-}\right)$. UV-vis in $\mathrm{MeOH}, \lambda, \mathrm{nm}\left(\varepsilon, \mathrm{M}^{-1} \mathrm{~cm}^{-1}\right) 623$ (562), 359 (7167), 289 (11433), 252 (12963), 218 (12520). IR (ATR, selected bands, Vmax, $\mathrm{cm}^{-1}$ ) 3368, 3294, 3065, 2979, 2915, 2731, 2693, 1643, 1554, 1398, 1305, 1169, 1049.

[Fe( $\left.\left(\mathrm{HL}^{2}\right) \mathrm{Cl}_{2}\right] \cdot 1.6 \mathrm{H}_{2} \mathrm{O}\left(2 \cdot 1.6 \mathrm{H}_{2} \mathrm{O}\right)$. To a solution of $\mathrm{H}_{2} \mathrm{~L}^{2} \cdot 2 \mathrm{H}_{2} \mathrm{O}(0.24 \mathrm{~g}, 0.56 \mathrm{mmol})$ in methanol $(70 \mathrm{~mL})$ a solution of $\mathrm{FeCl}_{3} \cdot 6 \mathrm{H}_{2} \mathrm{O}(0.21 \mathrm{~g}, 0.78 \mathrm{mmol})$ in methanol $(6 \mathrm{~mL})$ was added. The reaction mixture was stirred at room temperature for $1 \mathrm{~h}$. A green solution was evapourated under reduced pressure to ca. $10 \mathrm{~mL}$. Crystals of X-ray diffraction quality were obtained after ca. 7 days by vapour diffusion of diethyl ether into the concentrated reaction mixture. These were filtered off, washed with diethyl ether (20 $\mathrm{mL}$ ) and dried in vacuo overnight. Yield: $0.10 \mathrm{~g}, 32.8 \%$. Anal. Calc. for $\mathrm{C}_{19} \mathrm{H}_{25} \mathrm{Cl}_{2} \mathrm{FeN}_{4} \mathrm{O}_{3} \mathrm{~S} \cdot 1.6 \mathrm{H}_{2} \mathrm{O}\left(\mathrm{Mr}_{\mathrm{r}} 545.07\right)$ : C 41.87, $\mathrm{H} 5.21, \mathrm{~N}$ 10.28, S 5.88; Found: $\mathrm{C}$ 
41.80, $\mathrm{H}$ 4.92, $\mathrm{N}$ 9.93, S 5.71. ESI-MS in $\mathrm{MeOH}$ (negative): $\mathrm{m} / z 514\left(\left[\mathrm{Fe}\left(\mathrm{L}^{2}\right) \mathrm{Cl}_{2}\right]^{-}\right)$. ESIMS in $\mathrm{MeOH}$ (positive): $\mathrm{m} / \mathrm{z} 444\left(\left[\mathrm{Fe}\left(\mathrm{L}^{2}\right)\right]^{+}\right), 480\left(\left[\mathrm{Fe}\left(\mathrm{HL}^{2}\right) \mathrm{Cl}\right]^{+}\right)$. UV-vis in $\mathrm{MeOH}, \lambda, \mathrm{nm}$ $\left(\varepsilon, \mathrm{M}^{-1} \mathrm{~cm}^{-1}\right) 621$ (840), 474 sh, 366 (9853), 290 (18981), 267 (16253), 223 (17484). IR (ATR, selected bands, $\mathrm{V}_{\max } \mathrm{cm}^{-1}$ ) 2973, 2878, 2836, 1724, 1583, 1488, 1445, 1360, 1324, 1233, 1188, 1106, 1041, 993.

[ $\left.\mathrm{Fe}\left(\mathrm{HL}^{3}\right)(\mathrm{MeOH}) \mathrm{Cl}_{2}\right] \cdot 0.5 \mathrm{H}_{2} \mathrm{O}\left(\mathbf{3} \cdot \mathbf{0 . 5} \mathrm{H}_{2} \mathrm{O}\right)$. To a solution of $\mathrm{H}_{2} \mathrm{~L}^{3} \cdot 2 \mathrm{H}_{2} \mathrm{O}(0.14 \mathrm{~g}, 0.33$ $\mathrm{mmol})$ in methanol $(70 \mathrm{~mL})$ a solution of $\mathrm{FeCl}_{3} \cdot 6 \mathrm{H}_{2} \mathrm{O}(0.12 \mathrm{~g}, 0.43 \mathrm{mmol})$ in methanol $(6$ $\mathrm{mL}$ ) was added. The reaction mixture was stirred at room temperature for $2 \mathrm{~h}$. The dark brown solution was evapourated under reduced pressure to ca. $10 \mathrm{~mL}$. The crystalline solid was obtained after ca. 10 days by vapour diffusion of diethyl ether $\left(\mathrm{Et}_{2} \mathrm{O}\right)$ into the methanolic solution of the complex. The product was filtered off, washed with diethyl ether $(10 \mathrm{~mL})$ and dried in vacuo. Yield: $0.12 \mathrm{~g}, 61.0 \%$. Anal. Calc. for $\mathrm{C}_{22} \mathrm{H}_{27} \mathrm{Cl}_{2} \mathrm{FeN}_{4} \mathrm{O}_{4} \mathrm{~S} \cdot 0.5 \mathrm{H}_{2} \mathrm{O}$ ( $\mathrm{Mr}_{\mathrm{r}}$ 579.30): C 45.61, H 4.87, N 9.67, S 5.54; Found: C 45.56, H 4.74, N 9.95, S 5.60. ESI-MS in MeOH (positive): $\mathrm{m} / z 466$ ([Fe( $\left.\left.\left.\mathrm{L}^{3}\right)\right]^{+}\right), 502$ $\left(\left[\mathrm{Fe}\left(\mathrm{HL}^{3}\right) \mathrm{Cl}\right]^{+}\right), 538\left(\left[\mathrm{Fe}\left(\mathrm{H}_{2} \mathrm{~L}^{3}\right) \mathrm{Cl}_{2}+\mathrm{H}\right]^{+}\right)$. ESI-MS in $\mathrm{MeOH}$ (negative): $\mathrm{m} / z 537$ $\left(\left[\mathrm{Fe}\left(\mathrm{L}^{3}\right) \mathrm{Cl}_{2}\right]^{-}\right)$. UV-vis in $\mathrm{MeOH}, \lambda, \mathrm{nm}\left(\varepsilon, \mathrm{M}^{-1} \mathrm{~cm}^{-1}\right) 547$ (1577), 489 (1848), 373 (12522), 316 (14178), 293 sh, 260 sh, 230 (18771), 203 (18908). IR (ATR, selected bands, $v_{\max }$ $\mathrm{cm}^{-1}$ ) 3650, 2875, 1632, 1587, 1556, 1492, 1449, 1408, 1345, 1169, 1131, 1059, 1002, 961.

$\left[\mathrm{Fe}\left(\mathrm{HL}^{4}\right)(\mathrm{MeOH}) \mathrm{Cl}_{2}\right] \cdot \mathbf{0 . 5} \mathrm{H}_{2} \mathrm{O}\left(\mathbf{4} \cdot \mathbf{0 . 5} \mathrm{H}_{2} \mathrm{O}\right)$. To a solution of $\mathbf{H}_{2} \mathrm{~L}^{4} \cdot 2 \mathrm{H}_{2} \mathrm{O}(0.10 \mathrm{~g} ; 2.01$ $\mathrm{mmol})$ in ethanol/water $(3: 2)(75 \mathrm{~mL})$ a solution of $\mathrm{FeCl}_{3} \cdot 6 \mathrm{H}_{2} \mathrm{O}(0.067 \mathrm{~g}, 2.48 \mathrm{mmol})$ in ethanol $(5 \mathrm{~mL})$ was added. The reaction mixture was stirred at room temperature overnight. The solvent was removed under reduced pressure and residue was dissolved in methanol $(5 \mathrm{~mL})$. After addition of $\mathrm{Et}_{2} \mathrm{O}(50 \mathrm{~mL})$ the precipitate was filtered off, washed with $\mathrm{Et}_{2} \mathrm{O}(10 \mathrm{~mL})$ and dried in vacuo overnight. Yield: $0.076 \mathrm{~g}, 59.4 \%$. Anal. Calc. for $\mathrm{C}_{26} \mathrm{H}_{29} \mathrm{Cl}_{2} \mathrm{FeN}_{4} \mathrm{O}_{4} \mathrm{~S} \cdot 0.5 \mathrm{H}_{2} \mathrm{O}$ (Mr 629.36): C 49.62, H 4.80, N 8.90, S 5.09; Found: C 49.50, H 4.49, N 8.81, S 4.94. ESI-MS in MeOH (positive): $m / z 516$ ([Fe( $\left.\left.\left(\mathrm{L}^{4}\right)\right]^{+}\right)$. ESI-MS in $\mathrm{MeOH}$ (negative): $\mathrm{m} / z 586\left(\left[\mathrm{Fe}\left(\mathrm{L}^{4}\right) \mathrm{Cl}_{2}\right]^{-}\right)$. UV-vis in $\mathrm{MeOH}, \lambda, \mathrm{nm}\left(\varepsilon, \mathrm{M}^{-1} \mathrm{~cm}^{-1}\right)$ 
551 (1377), 358 (13871), 293 (16636), 249 sh. IR (ATR, selected bands, $v_{\max } \mathrm{cm}^{-1}$ ): 3655, 2967, 2920, 1730, 1560, 1447, 1397, 1319, 1265, 1232, 1169, 1070, 1009, 924.

$\left[\mathrm{Fe}\left(\mathrm{HL}^{4}\right)\left(\mathrm{dmf}^{2} \mathrm{Cl}_{2}\right] \cdot 0.5 \mathrm{Et}_{2} \mathrm{O} \cdot \mathrm{H}_{2} \mathrm{O}\left(\mathbf{4}^{\prime} \cdot \mathbf{0 . 5} \mathrm{Et}_{2} \mathrm{O} \cdot \mathrm{H}_{2} \mathrm{O}\right)\right.$. Complex $4(7 \mathrm{mg})$ was dissolved in dimethylformamide $(\mathrm{dmf})(0.6 \mathrm{~mL})$. Vapour diffusion of $\mathrm{Et}_{2} \mathrm{O}$ into $\mathrm{dmf}$ solution of 4 yielded X-ray diffraction quality crystals of $4^{\prime}$. Yield: $5.5 \mathrm{mg}, 75.8 \%$. Anal. Calc. for $\mathrm{C}_{28} \mathrm{H}_{32} \mathrm{Cl}_{2} \mathrm{FeN}_{5} \mathrm{O}_{4} \mathrm{~S} \cdot 0.5 \mathrm{Et}_{2} \mathrm{O} \cdot \mathrm{H}_{2} \mathrm{O}\left(M_{\mathrm{r}} 716.48\right): \mathrm{C}$ 50.29, H 5.49, N 9.77, S 4.48; Found: $\mathrm{C}$ 50.04, H 5.12, N 9.82, S 4.20. ESI-MS in $\mathrm{MeOH}$ (positive): $\mathrm{m} / z 516\left(\left[\mathrm{Fe}\left(\mathrm{L}^{4}\right)\right]^{+}\right), 589$ $\left(\left[\mathrm{Fe}\left(\mathrm{HL}^{4}\right) \mathrm{Cl}_{2}+\mathrm{H}\right]^{+}\right)$. ESI-MS in $\mathrm{MeOH}$ (negative): $\mathrm{m} / \mathrm{z} 586\left(\left[\mathrm{Fe}\left(\mathrm{L}^{4}\right) \mathrm{Cl}_{2}\right]^{-}\right), 550$ ([Fe( $\left.\left.\left.\left(\mathrm{HL}^{4}\right) \mathrm{Cl}\right]^{-}\right), 459\left(\mathrm{HL}^{-}\right)\right)$. UV-vis in dmf, $\lambda, \mathrm{nm}\left(\varepsilon, \mathrm{M}^{-1} \mathrm{~cm}^{-1}\right) 548 \mathrm{sh}, 368$ (12066), 307 (13043). IR (ATR, selected bands, $V_{\max } \mathrm{cm}^{-1}$ ): 3060, 2966, 2926, 2858, 2654, 2326, 1987, 1672, 1638, 1593, 1565, 1459, 1384, 1322, 1259, 1227, 1171, 1117, 1067, 1007, $971,875,828,771,679,605$.

Crystallographic structure determination. X-ray diffraction measurements of the complexes 1-3 were performed on Bruker D8 Venture (or Bruker X8 APEXII CCD) and of the complex 4' on STOE StadiVari diffractometer (detector Dectris Pilatus $300 \mathrm{~K}$, microfocus source Incoatec I $\mu \mathrm{S} \mathrm{Cu}(\mathrm{Cu}-\mathrm{Ka}, \lambda=1.54184 \AA)$ at $100 \mathrm{~K})$. Bruker diffractometer was equipped with an Oxford Cryosystem nitrogen gas open-flow cooler and Stoe StadiVari with a nitrogen gas open-flow Cobra from Oxford Cryosystem. The proline carbon atom $\mathrm{C} 12 \mathrm{~B}$ and pyrrolidine carbon atoms $\mathrm{C} 17 \mathrm{~B}$ and $\mathrm{C} 18 \mathrm{~B}$ in one of the two crystallographically independent molecules in $\mathbf{2}$ were found to be disordered over two positions with site occupation factors (s.o.f.) 0.70 to 0.30 and 0.60 to 0.40 , respectively. The disorder involving the proline carbon atoms $\mathrm{C} 12 \mathrm{~B}$ and $\mathrm{C} 13 \mathrm{~B}$ and coordinated methanol carbon atom C22B in $\mathbf{3}$ was also resolved over two positions with s.o.f. 0.75 to 0.25 , while that of carbon atom C9 in $4^{\prime}$ with s.o.f. 0.60 to 0.40 . In all cases the disorder was resolved by using SADI and EADP restraints implemented in SHELXL. Some electron density in the crystal structure of 2 was found in special positions and these were modelled as partly occupied with diethyl ether and water molecules. The site population was obtained from thermal parameters upon refinement with further constraints to the composition $2 \cdot 0.2 \mathrm{CH}_{3} \mathrm{OH} \cdot 0.125 \mathrm{Et}_{2} \mathrm{O} \cdot 0.063 \mathrm{H}_{2} \mathrm{O}$. The software 
programs used for structure solution were SHELXS- $97^{39}$ and X-Area STOE, ${ }^{40}$ for structure refinement SHELXL-9739 and XD2006, respectively and for molecular diagrams ORTEP-3. ${ }^{41}$ CCDC $1557747-1557750$.

Physical measurements. Elemental analysis of all compounds was performed on a Perkin Elmer $2400 \mathrm{CHN}$ Elemental Analyser (Perkin Elmer, Waltam, MA) at the Microanalytical Laboratory of the University of Vienna. Microanalytical data are within $\pm 0.4 \%$ of the calculated values. Electrospray ionisation mass spectrometry measurements were carried out on a Bruker Esquire 3000 instrument (Bruker Daltonic, Bremen, Germany) at Mass Sprectrometry Centre of the Faculty of Chemistry (University of Vienna). UV-vis spectra were measured on a Perkin-Elmer Lambda 650 spectrophotometer. The samples were prepared by dissolving the compounds in $\mathrm{MeOH}$, dmf or solvent mixture $\mathrm{MeOH} / \mathrm{H}_{2} \mathrm{O} 1: 1$ before measurement (900-210 nm). Infrared spectra were recorded on Perkin-Elmer FT-IR 2000 instrument $\left(400-400 \mathrm{~cm}^{-1}\right)$ using ATR unit or Bruker Vertex 70 FT-IR spectrometer. NMR spectra were acquired on a Bruker Avance III $500 \mathrm{MHz}$ FT-NMR spectrometer by using as a solvent $\left(\mathrm{CD}_{3}\right)_{2} \mathrm{SO}$. Magnetic measurements were carried out on microcrystalline samples 2 and $\mathbf{4}$ with a Quantum Design SQUID magnetometer (MPMS-XL) at $0.1 \mathrm{~T}$ in the temperature range 2-300 K. Data were corrected for the contribution of the sample holder and diamagnetism of the samples estimated from Pascal's constants. ${ }^{42}$

Electrochemistry measurements. For cyclic voltammetry experiments commercially available acetonitrile ( $\mathrm{MeCN}$ ) Secco Solv (dried, max. 0.005\% $\mathrm{H}_{2} \mathrm{O}$ ) from Merck, and ferrocene $(\mathrm{Fc})$ purchased from Sigma Aldrich were used without further purification. Tetrabutylammonium hexafluorophosphate $\left(n \mathrm{Bu}_{4} \mathrm{NPF}_{6}\right)$ of purissimum quality (Fluka) was dried under reduced pressure at $70{ }^{\circ} \mathrm{C}$ for $24 \mathrm{~h}$. Cyclic voltammograms of the complexes in $\mathrm{MeCN}(1 \mathrm{mM})$ containing $0.1 \mathrm{M} \mathrm{nBu4NPF} 6$ as the supporting electrolyte were measured using a one-compartment electrochemical cell with platinum wires as the working and counter electrodes and a silver wire as the pseudoreference electrode. All electrochemical measurements were performed under nitrogen atmosphere. Cyclic voltammograms were measured using a HEKA PG 390 potentiostat at room 
temperature. DigiElch Professional software from Gamry Instruments (USA), version DigiElch8, was used for digital simulations of cyclic voltammograms

\section{Cytotoxicity assay}

Cell lines and culture conditions. Human cervical carcinoma (HeLa), human melanoma (FemX), human alveolar basal adenocarcinoma (A549), human breast cancer (MDA-MB-453), colon cancer cell line (LS-174), murine transformed endothelial cell line (MS1) and normal lung fetal fibroblast cell line (MRC-5) were maintained as monolayer culture in the Roswell Park Memorial Institute (RPMI) 1640 nutrient medium (Sigma Chemicals Co, USA). RPMI 1640 nutrient medium was prepared in sterile ionised water, supplemented with penicilin (192 IU mL $\left.\mathrm{mL}^{-1}\right)$, streptomycin $\left(200 \mathrm{mg} \mathrm{mL}^{-1}\right)$, 4-(2-hydroxyethyl)piperazine-1-ethanesulfonic acid (HEPES) (25 mM), L-glutamine (3 $\mathrm{mM})$ and $10 \%$ of heat-inactivated fetal calf serum (FCS; pH 7.2). The cells were grown at $37{ }^{\circ} \mathrm{C}$ in $5 \% \quad \mathrm{CO}_{2}$ and humidified in air atmosphere, by twice weekly subculture.

MTT assay. Antiproliferative activity of the compounds was determined using 3-(4,5dimethylthiazol-yl)-2,5-diphenyltetrazolium bromide (MTT, Sigma Aldrich) assay. ${ }^{43}$ Cells were seeded into 96-well cell culture plates (Thermo Scientific Nunc) in an appropriate density for each cell line. After $24 \mathrm{~h}$ of growth, cells were exposed to the serial dilutions of the tested compounds. The compounds were dissolved in minimum amount of dimethyl sulfoxide (dmso) and afterwards diluted with nutrient medium to desired final concentrations (in the range up to $300 \mu \mathrm{M}$ ). The amount of dmso in prepared solutions was $\leq 1 \%$. Each concentration was tested in triplicate. After incubation period of $48 \mathrm{~h}$, $20 \mu \mathrm{L}$ of MTT solutions (5 mg mL $\mathrm{mL}^{-1}$ in phosphate buffer solution, $\mathrm{pH} 7.2$ ) were added to each well. Samples were incubated at $37{ }^{\circ} \mathrm{C}$ with $5 \% \mathrm{CO}_{2}$ in a humidified atmosphere for $4 \mathrm{~h}$. Formazan crystals were dissolved in $100 \mu \mathrm{M}$ of $10 \%$ sodium dodecyl sulfate (SDS). Absorbance values were recorded after $24 \mathrm{~h}$, on an ELISA reader (ThermoLabsystem Multiskan EX 200-240 V) at the wavelength of $570 \mathrm{~nm}$. The IC50 
values, defined as the concentrations of the compound causing $50 \%$ cell growth inhibition, were estimated from the dose-response curves.

\section{Acknowledgements}

This study was financially supported by the Austrian Science Fund (project number P28223-N34), Research and Development Agency of the Slovak Republic under the contracts No. APVV-15-0079 and APVV-15-0053, Scientific Grant Agency of the Slovak Republic (VEGA Project 1/0871/16) and Slovak University of Technology in Bratislava (Young Researcher Grant, M. Milunović, PhD). This work was also supported by Ministry of Education, Science, Research and Sport of the Slovak Republic within the Research and Development Operational Program for the project "University Science Park of STU Bratislava", ITMS 26240220084, co-funded by the European Regional Development Fund.

\section{Author Information}

Corresponding Authors

E-mail: miljan.milunovic@univie.ac.at; vladimir.arion@univie.ac.at

\section{Notes}

The authors declare no competing financial interest.

\section{References}

[1] a) D. X. West, S. B. Padhye, P. B. Sonawane, Struct. Bonding 1991, 76, 1-50; b) T.

S. Lobana, R. Sharma, G. Bawa, S Khanna, Coord. Chem. Rev. 2009, 253, 977-1055;

c) T. S. Lobana, RSC Adv. 2015, 5, 37231-37274.

[2] Y. Yu, D. S. Kalinowski, Z. Kovacevic, A. R. Siafakas, P. J. Jansson, C. Stefani, D. B. Lovejoy, P. C. Sharpe, P. V. Bernhardt, D. R. Richardson, J. Med. Chem. 2009, 52, 5271-5294.

[3] H. Beraldo, D. Gambino, Mini Rev. Med. Chem. 2004, 4, 31-39.

[4] D. Hamre, J. Bernstein, R. Donvick, Proc. Soc. Exper. Biol. \& Med. 1950, 73, 275278. 
[5] R. C. DeConti, B. R. Toftness, K. C. Agrawal, R. Tomchick, J. A. R. Mead, J. R.

Bertino, A. C. Sartorelli, W. A. Creasey, Cancer Res. 1972, 32, 1455-1462.

[6] I. H. Krakoff, E. Etcubanas, C. Tan. K. Mayer, V. Bethune, J. H. Burchenal, Cancer Chemother. Rep. 1974, 58, 207-212.

[7] M. -C. Liu, T. -S. Lin, A. C. Sartorelli, J. Med. Chem. 1992, 35, 3672-3677.

[8] C. Stefani, P. J. Jansson, E. Gutierrez, P. V. Bernhardt and D. Richardson, J. Med. Chem. 2013, 56, 357-370. (ref. therein)

[9] P. Nordlund, P. Reichard, Annu. Rev. Biochem. 2006, 75, 681-706.

[10] B. M. Zeglis, V. Divilov, J. S. Lewis, J. Med. Chem. 2011, 54, 2391-2398.

[11] J. Yuan, D. B. Lovejoy, D. R. Richardson, Blood 2004, 104, 1450-1458.

[12] C. P. Wu, S. Shukla, A. M. Calcagno, M. D. Hall, M. M. Gottesman, S. V.

Ambudkar, Mol. Cancer. Ther. 2007, 6, 3287-3296.

[13] S. Sahni, D.-H. Bae, D. J. R. Lane, Z. Kovacevic, D. S. Kalinowski, P. J. Jansson, D. R. Richardson, J. Biol. Chem. 2014, 289, 9692-9709.

[14] P. J. Jansson, D. S. Kalinowski, D. J. Lane, Z. Kovacevic, N. A. Seebacher, L.

Fouani, S. Sahni, A. M. Merlot, D. R. Richardson, Pharmacol. Res. 2015, 100, 255-260. [15] I. Đilovic, M. Rubcic, V. Vrdoljak, S. K. Pavelic, M. Kralj, I. Piantanida, M. Cindric, Bioorg. Med. Chem. 2008, 16, 5189-5198.

[16] C. R. Kowol, R. Trondl, P. Heffeter, V. B. Arion, M. A. Jakupec, A. Roller, M. Galanski, W. Berger, B. K. Keppler, J. Med. Chem. 2009, 52, 5032-5043.

[17] C. Stefani, G. Punnia-Moorthy, D. B. Lovejoy, P. J. Jansson, D. S. Kalinowski, P.C. Sharpe, P. V. Bernhardt, D. Richardson, J. Med. Chem. 2011, 54, 6936-6948.

[18] M. N. M. Milunovic, E. A. Enyedy, N. V. Nagy, T. Kiss, R. Trondl, M. A. Jakupec, B. K. Keppler, R. Krachler, G. Novitchi, V. B. Arion, Inorg. Chem. 2012, 51, 9309-9321. [19] https://clinicaltrials.gov/ct2/show/NCT02433626. Accessed on 24/06/2017. [20] K. Y. Salim, S. M. Vareki, W. R. Danter, J. Koropatnick, Oncotarget 2016, 7, 4136341379.

[21] F. Bacher, E. A. Enyedy, N. V. Nagy, A. Rockenbauer, G. M. Bognar, R. Trondl, M. S. Novak, E. Klapproth, T. Kiss, V. B. Arion, Inorg. Chem. 2013, 52, 8895-8908. 
[22] S. Ishida, P. Andreux, C. Poitry-Yamate, J. Auwerx, D. Hanahan, Proc. Natl. Acad. Sci. U.S.A. 2013, 110, 19507-19512.

[23] Y. Gou, J. Wang, S. Chen, Z. Zhang, Y. Zhang, W. Zhang, F. Yang, Eur. J. Med. Chem. 2016, 123, 354-364.

[24] J. Qi, Y. Gou, Y. Zhang, K. Yang, S. Chen, L. Liu, X. Wu, T. Wang, W. Zhang, F. Yang, J. Med. Chem. 2016, 59, 7497-7511.

[25] A. Popovic-Bijelic, C. R. Kowol, M. E. S. Lind, J. Luo, F. Himo, E. A. Enyedy, V. B. Arion, A, Gräslund, J. Inorg. Biochem. 2011, 105, 1422-1431.

[26] J. M. Phang, W. Liu, C. N. Hancock, J. W. Fisher, Curr. Opin. Clin. Nutr. Metab. Care, 2015, 18, 71-77.

[27] O. J. Patino, L. E. Cuca, Phytochem. Lett. 2011, 4, 22-25.

[28] A. Dobrova, S. Platzer, F. Bacher, M. N. M. Milunovic, A Dobrov, G. Spengler, E. A. Enyedy, G. Novitchi, V. B. Arion, Dalton Trans. 2016, 45, 13427-13439.

[29] A. W. Addison, T. N. Rao, J. Reedijk, J. van Rijn, G. C, J. Chem. Soc. Dalton Trans. 1984, 1349-1356.

[30] D. Carmona, M. P. Lamata, F. Viguri, I. Dobrinovich, F. L. Lahoz, L. A. Oro, Adv. Synth. Catal. 2002, 344, 499-502.

[31] E. A. Enyedy, M. F. Primik, C. R. Kowol, V. B. Arion, T. Kiss, B. K. Keppler, Dalton Trans. 2011, 40, 5895-5905.

[32] O. Kahn, Molecular Magnetism, VCH Publishers, Inc., New York, Weinheim, Cambridge, 1993.

[33] D. Gatteschi, R. Sessoli and J. Villain, Molecular Nanomagnets, Oxford University Press, Oxford, 2006.

[34] V. V. Pavlishchuk, A. W. Addison, Inorg. Chim. Acta 2000, 298, 97-102.

[35] D. R. Richardson, P. C. Sharpe, D. B. Lovejoy, D. Senaratne, D. S. Kalinowski, M. Islam, P. V. Bernhardt, J. Med. Chem. 2006, 49, 6510-6521.

[36] D. S. Kalinowski, P. C. Sharpe, P. V. Bernhardt, D. R. Richardson, J. Med. Chem. 2007, 50, 6212-6225. 
[37] F. Bacher, O. Domotor, M. Kaltenbrunner, M. Mojovic, A. Popovic-Bijelic, A. Graslund, A. Ozarowski, L. Filipovic, S. Radulovic, E. A. Enyedy, V. B. Arion, Inorg. Chem. 2014, 53, 12595-12609.

[38] A. Basu, G. Das, Dalton Trans. 2011, 40, 2837-2843.

[39] G. M. Sheldrick, Acta Crystallogr., Sect. A: Fundam. Crystallogr. 2008, 64, 112-122. [40] STOE \& Cie GmbH (2016). X-Area 1.76, software package for collecting singlecrystal data on STOE area-detector diffractometers, for image processing, scaling reflection intensities and for outlier rejection; Darmstadt, Germany [41] M. N. Burnett, G. K. Johnson. ORTEPIII, Report ORNL-5138; Oak Ridge National Laboratory: Oak Ridge, TN, 1996.

[42] G. A. Bain, J. F. Berry, J. Chem. Educ. 2008, 85, 532-536.

[43] R. Supino, In Vitro Toxicity Testing Protocols, Springer, New York, 1995, 37-149. 
Table of Contents

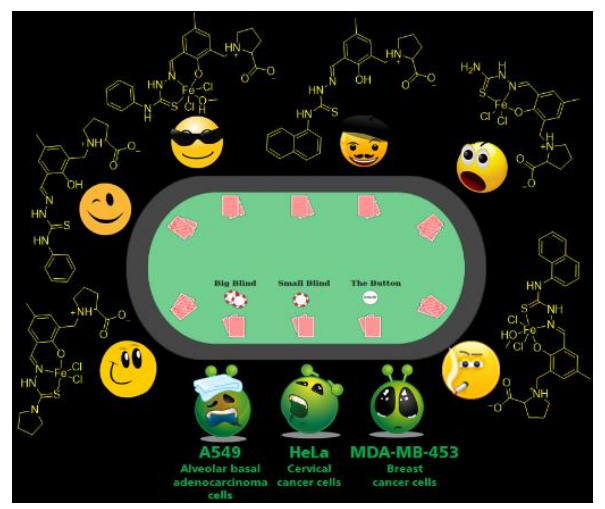

$\mathrm{N}$-substituted thiosemicarbazone-proline hybrids and their iron(III) complexes were synthesized and characterized. The antiproliferative activity of all hybrids and iron(III) complexes was investigated in five human and one murine cancer cell lines. Introduction of aromatic groups and coordination to iron(III) increase the cytotoxic potential of the proligands.

\section{(Anticancer) drug development}

Miljan N. M. Milunović, * Aliona Dobrova, Novitchi Ghenadie, Nevenka Gligorijević, Siniša Radulović, Jozef Kožišek, Peter Rapta, Eva A. Enyedy, Vladimir B. Arion*

Page No.- Page No.

Effects of Terminal Substitution and Iron Coordination on Antiproliferative Activity of L-Proline-salicylaldehyde Thiosemicarbazone Hybrids 